\title{
Quotas and Quality: The Effect of H-1B Visa Restrictions on the Pool of Prospective Undergraduate Students from Abroad*
}

\author{
Takao Kato Khad Sparber $^{\ddagger}$
}

May 2010

\begin{abstract}
In deliberating whether to pursue an undergraduate education in the US, a foreign student takes into consideration the expected probability of securing US employment after graduation. The $\mathrm{H}-1 \mathrm{~B}$ visa provides a primary means of legal employment for college-educated foreign-nationals. In October 2003, the government drastically reduced the number of available H-1B visas, hence lowering the probability of a college-educated foreign-national finding employment, and possibly discouraging highly qualified international students from attending US colleges and universities. However, citizens from five countries are de facto exempt from the $2003 \mathrm{H}-1 \mathrm{~B}$ visa restrictions. Using international students from these five exempt nations as the control and other international students as the treatment group, we study the effects of the $2003 \mathrm{H}-1 \mathrm{~B}$ policy change on the pool of international applicants to US schools. We use two datasets: (i) College Board SAT score data on prospective international applicants; and (ii) SAT and high-school GPA data on international applicants to a single highly selective university. Our fixed effect estimates show that the restrictive immigration policy has had an adverse impact on the quality of prospective international applicants, reducing their SAT scores by about $1.5 \%$. This effect is driven mostly by a decline in the number of SAT score reports sent by international students at the top-quintile of the SAT score distribution, suggesting that the restrictive immigration policy disproportionately discourages high-ability international students from attending US schools. Our results are robust to alternative specifications, including the use of high-school GPA as a measure of applicant ability.

Key Words: Skilled Immigration, H-1B Visa, College Education, SAT Scores

JEL Classification Codes: F22, I20, O15, I28, J61
\end{abstract}

\footnotetext{
*Jessica Mawhirt, Kelly Motta, and Hejia Wang supplied valuable research assistance. We thank Eric Larsen, Todd Sorensen, and seminar participants at the University of Connecticut for helpful comments and suggestions. Sparber thanks the University of Puget Sound for providing summer research support.

${ }^{\dagger}$ Kato is W.S. Schupf Professor of Economics and Far Eastern Studies, Colgate University (tkato@colgate.edu; 13 Oak Drive, Hamilton, NY 13346; 315-228-7562); Research Fellow, IZA Bonn; and Research Associate, Center on Japanese Economy and Business (Columbia Business School), Tokyo Center for Economic Research (University of Tokyo), and Center for Corporate Performance (Aarhus School of Business).

${ }^{\ddagger}$ Sparber is Assistant Professor of Economics, Colgate University (csparber@colgate.edu; 13 Oak Drive, Hamilton, NY 13346; 315-228-7967); and External Research Fellow, Centre for Research and Analysis of Migration (CReAM), University College London.
} 


\section{Introduction}

Foreign students often study in the United States hoping that an American undergraduate education will serve as a gateway to longer-term US employment. Rosenzweig (2006) provides strong empirical support for this phenomenon. Moreover, Borjas (2002) notes that the probability of ultimately receiving a green card (permanent residency) was 26 times higher for foreign students than for those applying through the random green card lottery. Clark, Hatton, and Williamson (2007), Bhagwati and Rao (1999), and Chiswick (1999) are among other authors to claim that student visas (or temporary worker visas) are often used in hopes of securing permanent employment.

The H-1B visa offers many foreign-nationals with a college degree a legal, though temporary, permit to work in the United States. It is granted for a three-year period, renewable for a total of six years, and is only available to individuals in professional occupations requiring "the theoretical and practical application of a body of highly specialized knowledge requiring completion of a specific course of higher education." ${ }^{1}$ Congressionally-imposed limits on new H-1B issuances per annum have fluctuated widely, rising from its inaugural cap of 65,000 in fiscal year 1992 to 115,000 in fiscal years 1999 and 2000, further increasing to 195,000 in 2001, 2002, and 2003, then reverting to the initial 65,000 level in fiscal year 2004 and beyond. Although not all visa issuances count toward the cap, current policy is clearly restricting college-educated foreign-nationals' access to the US labor market.

Figure 1 provides descriptive evidence that countries with a large number of undergraduates enrolled in US institutions also have a large number of citizens working on an $\mathrm{H}-1 \mathrm{~B}$ visa. A simple cross-country regression (not shown) of H-1B issuances (in fiscal year 2006) on undergraduate enrollment (in academic year 2001/02) and Population (2002), all measured in logs, reveals an elasticity estimates of 1.10 that is significantly different from zero but not from one. That is, a $1 \%$ rise in college enrollment is associated with an equivalent rise in H-1B visas issued four years later, controlling for country population size. ${ }^{2}$ As such, it appears that foreign-nationals view US education as a route to US employment.

Since foreign-student interest in a US degree is partly driven by the hope that it will improve access to the US labor market, policies reducing H-1B visas are likely to deter foreign students from pursuing tertiary American education. That visa quotas in general reduce US immigrant flows is an

\footnotetext{
${ }^{1}$ See the US State Department website, http://travel.state.gov/visa/temp/types/types_1271.html

${ }^{2} \mathrm{H}-1 \mathrm{~B}$ data is from "Non-immigrant visa issuances by visa class and by nationality" at the US Department of State, http://www.travel.state.gov/visa/frvi/statistics/statistics_4396.html. Enrollment data is from the Institute of International Education Data, "All Places of Origin and By Place of Origin and Academic Level," http://opendoors.iienetwork.org/?p=28633. The World Bank's "World Development Indicators" provides population data.
} 
already well-established phenomena in the literature. ${ }^{3}$ This paper instead assesses how restrictive H1B policy has affected the academic quality (or ability) of prospective international students, including an analysis of how the number of prospective students at each quintile of the ability distribution has changed in response to policy.

Section 2 begins with a discussion of past literature and motivation. Section 3 turns to our empirical strategy, including a simple theory to motivate the empirical analysis, a brief history of $\mathrm{H}-1 \mathrm{~B}$ policy and legislation, and a discussion of data measurement. Importantly, college-educated citizens of five key countries - Australia, Canada, Chile, Mexico, and Singapore - can acquire work permits that are close substitutes for the $\mathrm{H}-1 \mathrm{~B}$ visa. Thus, workers from those countries are less bound by $\mathrm{H}-1 \mathrm{~B}$ restrictions. This allows us to identify the effect of current policy on the selection of foreign-student interest in US education.

Section 4 gives the results. We begin with a College Board dataset measuring the SAT scores of international test takers. We find that visa restrictions have reduced SAT scores of prospective students by about 20 points. Log-regressions suggest a loss of 1.5\%. The College Board dataset presents a few limitations, however. First, SAT scores are not the only relevant gauge of academic quality used by US college admission offices, and some researchers argue that high school GPAs are a superior measure (Geiser and Santelices, 2005 and Rask and Tiefenthaler, 2009). Though we believe that the use of SAT scores may be more justifiable than high school GPAs for international applicants, it is of significant value to test the robustness of our key results to the use of an alternative quality measure. Second, although the College Board provides data on prospective international students, we cannot be sure that all of them actually become college applicants. Finally, the dataset is complicated by timing issues. We cannot precisely identify dates in which students sent SAT score reports, which may be a problem for individuals taking the exam near policy change dates.

We turn to an alternative dataset that allows us to conduct a case-study of applicants to a highlyselective university to address these issues. This dataset provides a measure of standardized high school GPA, includes international applicants only, and is less encumbered by timing issues. Our case study analysis uncovers ability losses comparable in magnitude to those found using College Board data, pointing to the robustness of our findings.

\footnotetext{
${ }^{3}$ See Mayda (2009) and Clark, Hatton, and Williamson (2007) for recent evidence.
} 


\section{Literature and Motivation}

In political debate over immigration policy, Americans maintain more favorable attitudes toward highly-educated immigrants compared to less-educated ones. For example, a CBS News / New York Times Poll (2007) revealed that $51 \%$ of respondents believe US immigration policy should favor people based upon education and job skills - results echoed in a recent paper by Hainmueller and Hiscox (2010). US politicians are now considering a shift in immigration policy toward prioritizing skilled immigrants as evidenced by recent Congressional measures introduced by Senators Lindsey Graham and Charles Schumer. ${ }^{4}$ Despite these views, however, immigration among highly-educated workers remains controversial. The most recent (2003) policy change regarding the H-1B visa for skilled workers increased restrictions, ${ }^{5}$ while economists have highlighted the potential for both positive and negative effects. The economics of highly-educated immigration thus warrants additional attention.

Researchers who focus on the costs of skilled immigration emphasize distributional concerns. Hira (2007), Miano (2007), Stephan and Levin (2007), Borjas (2006), and Borjas (1999) all warn that highly-educated immigrants could reduce employment and wage opportunities for similarly-educated natives. This includes, for example, the proliferation of low-paying postdoc positions now expected of recent science Ph.D. graduates before finding permanent employment. Similarly, Borjas (2007) and Borjas (2002) worry that immigrants alter the educational plans of natives and crowd them out of science and engineering programs within universities. ${ }^{6}$

Even if immigrants are not explicitly crowding-out natives, it is clear that foreign-workers are becoming more prominent in US maths and sciences. Stephan and Levin (2007) quote an American Mathematical Society statistic that 40\% of US mathematics jobs in 1995 were awarded to immigrants. Levin et. al. (2004, p. 359) note that while the number of citizen science and engineering doctoral recipients living in the US rose three-fold between 1973-97, the number of non-citizen recipients had grown eight-fold. By 1997, 20\% of US scientists were non-citizens at the time of doctoral degree receipt. ${ }^{7}$

More sanguine views of highly-educated immigration focus on the far-reaching macroeconomic effects. Hunt (2009) demonstrates that immigrants are particularly innovative and entrepreneurial.

\footnotetext{
${ }^{4}$ See Preston (2010).

${ }^{5}$ The history of H-1B legislation will be detailed in Section 3.2.

${ }^{6}$ Peri and Sparber (2008), in contrast, suggest that comparative advantages among highly-educated native and foreignborn workers should protect natives from competition, and mitigate potential wage losses. Similarly, results in Kerr and Lincoln (2008) suggest that highly-educated workers on H-1B visas do not crowd out natives.

${ }^{7}$ Another concern might be one of brain-drain: origin countries suffer when skilled workers leave. However, recent empirical evidence in Rosenzweig (2006) and simulation results in Mayr and Peri (2009) suggest that origin countries actually benefit from emigration, since emigrants often return home with improved skill sets.
} 
Compared to natives, immigrants are more adept at patenting, licensing their patents, and publishing. This advantage of immigrants over natives is largely explained by educational differences between the two groups (degree and field of study). However, immigrants are more likely to start new companies than natives are, even after controlling for education. Kerr and Lincoln (2008) provide concurring evidence for the innovative gains of highly-educated immigration by focusing specifically on the $\mathrm{H}-1 \mathrm{~B}$ program. They argue that $\mathrm{H}-1 \mathrm{~B}$ admissions increase Indian, Chinese, and total patenting in cities and firms that are dependent upon highly-educated foreign-born workers. Further evidence for the technology and productivity enhancing effects of highly-educated immigration can be found in Hunt and Gauthier-Loiselle (2009), Stephan and Levin (2007), Chellaraj, Maskus, and Mattoo (2005), and Borjas (1999).

Freeman (2009) argues that the US's comparative advantage in science and technology is severely threatened by educational trends in the US and abroad. He reports that $29 \%$ of the world's college students were enrolled in US schools in 1970, but that figure declined to just $12 \%$ in 2006 . In the mid 1980s, 37.8\% of the world's students studying abroad chose to matriculate in US universities. That number declined to $20 \%$ in 2006-07. These declines will hit science and engineering fields particularly hard. Foreigners represented $15 \%$ of science and engineering workers with a bachelors degree and a third of those with a doctorate. Of those foreign-born workers, most were educated in the US. ${ }^{8}$ Freeman predicts that these trends together imply that wages of skilled US workers will decline, as will the price of US high-tech exports.

A key question surrounding immigration in general and unskilled immigration in particular is what determines the quantity of immigrant flow. Hence, determinants of the quantity of immigrant flows have been relatively well-researched at least since Sjaastad (1962), and gaining popularity after Borjas (1987). Most research employs a cross-section or panel of countries to assess the macroeconomic determinants of the quantity of aggregate migration flows. Mayda (2009), for example, employs a panel of 14 OECD destination countries and shows that pull factors (e.g., high GDP in destination countries) are more important than push factors (low GDP in origin countries) in driving migration decisions. As immigration policy in host countries becomes less restrictive, both push and pull factors become more important. Clark, Hatton, and Williamson (2007) provide a more direct test of the consequences of US immigration policy over 1971-1998. Using a panel of 81 source countries over 28 years, they report (p. 365), "The effects of immigration policy are discernible and have the expected effects... An increase in $10 \%$ in the family quota raises immigration from a country by $0.3 \%$. The same proportionate increase in employment visas raise it by $1.4 \%$. A $10 \%$ increase in the refugee

\footnotetext{
${ }^{8}$ See Freeman (2009) Exhibits 1, 7, and 10.
} 
allowance raises immigration by $0.5 \%$, while the effect of the diversity quota is minimal."

Less work has been done on the quality (as opposed to quantity) of immigrants. For research on skilled immigrants, however, quality issues may be even more important than quantity. Rosenzweig (2006) focuses on the determinants of foreign student flows. To him, students make an interesting case for analysis because student flows are considerably larger than other skill-based flows, while there is no country-specific or total ceiling on student visas. He proposes that students are likely to be particularly motivated by economics - other immigrant groups are often driven by family ties, or in the case of refugees, by political forces. His empirical results support this view. He finds that students immigrate not due to a lack of educational opportunity at home, but rather due to the lure of greater economic prosperity in the US. He concludes by arguing that foreign students go to the US in hopes of permanent employment, even though only a fraction actually remain after graduation.

Chiswick (2000) surveys the empirical literature and offers a theoretical model of migrant selectivity. He argues that migrants are favorably self-selected. If the direct costs of migration rise, or if ability is negatively correlated with the costs of migration, this favorable self-selectivity grows stronger. Chen (2005) provides a short case-study of the quality of masters degree students in a Chinese university and their interest in migrating to the US to continue their education. He finds that potential emigrants were negatively self-selected during a less-restrictive policy regime, but positively selected during a more-restrictive regime. However, he is vague about which policies were in question, and it is not clear that they would have targeted and/or restricted highly-educated workers.

In short, there is little if any disagreement among researchers about whether immigration quotas affect the quantity of immigration flows. On the other hand, researchers are much less unanimous about the effects on the quality of immigrants. For highly-educated immigration, the skills of those

who decide to migrate is at least as important as how many workers choose to do so. Sanguine views of immigration are discounted if the quality of the immigrant pool declines, while US higher education might also suffer. We aim to fill this important gap in the literature by providing rigorous evidence on the effects of restrictive immigration policy (reductions in H1-B quotas) on the quality of (potential) skilled immigrants.

\section{Empirical Strategy}

\subsection{Simple Theoretical Model of a Student's Migration Decision}

To better motivate the empirics and to illustrate that policy can affect the average abilities of foreign individuals considering a US education, consider a simple theoretical model of a student's migration 
decision. The intuition of the model is simple: Low ability foreign students are unlikely to find US employment even in the absence of visas quotas. Labor policy is irrelevant to their schooling location decisions. Quotas only affect foreign labor that US firms want to hire. Thus, high ability students may be deterred from US education by the decreased probability of finding legal employment after graduating.

More formally, let us assume that a foreign student applies to a US school based solely upon perceived labor market prospects upon graduation. Individual $i$ will apply only if the expected net-benefit $\left(N B_{i}\right)$ of US employment exceeds her reservation wage $\left(R_{i}\right)$ of either studying at home or pursuing her education in a foreign country other than the US (whichever yields a higher net benefit). Let us further suppose that both the net benefit and reservation wage experience positive but diminishing returns to ability $\left(a_{i}\right)$. This is because the probability of graduation, the probability of finding employment, and the earnings from employment are all increasing in ability, whereas the costs of migrating decrease in ability.

Finally, we allow the government to institute a random lottery to allocate a fixed number of work permits (akin to the US government's distribution of H-1B visas). The probability of receiving a visa equals $v$. If we simplify by assuming zero migration costs so that net benefit and gross benefit are equal, then foreign student $i$ applies to (or attends) a US university only if $v \cdot N B\left(a_{i}\right)>R\left(a_{i}\right)$. Changes in quotas disproportionately affect high ability individuals. Mathematically, this arises because $\frac{d\left(v \cdot N B\left(a_{i}\right)\right)}{d(v) d\left(a_{i}\right)}=\frac{d\left(N B\left(a_{i}\right)\right)}{d\left(a_{i}\right)}>0$. More intuitively, this might occur for two reasons. First, low-ability immigrants may be unlikely to secure desirable US employment even in the absence of visa restrictions - employment quotas are largely irrelevant. High-ability immigrants, in contrast, have no worry in finding attractive options under free mobility. They face substantially higher risk of unemployment when required to subject themselves to a random lottery, however. Second, high-ability foreign-nationals might simply be more aware of US policy changes. They would alter their college application decisions accordingly, whereas those ignorant of policy developments would exhibit no response. ${ }^{9}$

Figure 2 illustrates the effects of a restrictive policy that shifts $v_{0} \cdot N B\left(a_{i}\right)$ down to $v_{1} \cdot N B\left(a_{i}\right)$. The equilibrium and skill-level effects are determined by the relative concavity of $N B\left(a_{i}\right)$ and $R\left(a_{i}\right)$. In Panel A, the net benefit function is more concave than the reservation wage is. Immigrants come from the middle of the ability distribution. Restrictive policy discourages both the highest and lowest ability workers from immigrating. In Panel B, the net benefit function is less concave. Here, immigrants

\footnotetext{
${ }^{9}$ Our theory assumes no change in firm behavior. In practice, individuals can enter the H-1B lottery only after receiving a job offer from an employer willing to sponsor an application. If firms are hesitant to subject themselves to a lottery for low ability workers, restrictions could disproportionately affect low ability immigrants. Our empirics uncover no such result, however, so we omit this possibility from the theoretical model.
} 
come from the ability tails. Visa limits discourage the weakest of the still very good students from immigrating. It also deters the best of the lower ability students.

In both cases, the theoretical effect on the average quality of international applicants to US higher education would require additional assumptions regarding the distribution of individuals across the ability spectrum - Figure 2 simply illustrates potential changes in the ability thresholds determining migration decisions. Our theoretical effect of policy on average ability remains ambiguous since the model is silent on the numbers of individuals available at each point in the distribution. Instead, we advocate empirical analysis for further understanding.

\subsection{History of H-1B Policy}

The Immigration Act of 1990 (implemented in 1992) created the H-1B visa for professional (collegeeducated) foreign nationals seeking temporary employment in the United States. ${ }^{10}$ At that time, 65,000 H-1B visas became available for new applicants each year. The cap was not reached until fiscal year 1997 and again in 1998. In October of 1998, Congress enacted the American Competitiveness and Workforce Improvement Act (ACWIA), which temporarily raised the cap to 115,000 for fiscal years 1999 and 2000, and to 107,000 for 2001. The 1999 limit was accidentally exceeded by 22,000, an oversight for which the Immigration and Naturalization Service (INS) was ultimately forgiven. The 2000 limit was reached six months prior to the end of the fiscal year. Congress responded to the increase in demand for $\mathrm{H}-1 \mathrm{~B}$ visas with the American Competitiveness in the 21st Century Act (AC21) - signed by then-President Clinton in October 2000. The act reduced the number of H-1B visas that counted toward the quota, and also raised the cap to 195,000 for each of 2001, 2002, and 2003. Those limits were never reached; only about 78,000 visas counted toward the cap in 2003.

AC21 clearly stipulated that without further legislation, the H-1B cap would revert to 65,000 for fiscal year 2004 and beyond. Despite a trend for progressively less restrictive labor laws, Congress did not enact wide-ranging legislation to maintain the high quota. As a result, the H-1B cap has been binding every year since 2004. The US Citizenship and Immigration Service (USCIS) had initially reviewed H-1B petitions on a first-come first-served basis. In 2006, however, they began selecting petitions by lottery.

Importantly, country-specific free trade agreements have created close H-1B substitutes for citizens from five key countries - Canada, Mexico, Chile, Singapore, and Australia. The North American Free Trade Agreement created the TN visa for professionals from Canada and Mexico. ${ }^{11}$ Although the

\footnotetext{
${ }^{10}$ Kapur and McHale (2005) report that $98 \%$ of H-1B approvals go to individuals with a bachelors degree or more education.

${ }^{11}$ Canadians do not have to apply for $\mathrm{TN}$ or $\mathrm{H}-1 \mathrm{~B}$ visas, but must instead simply meet the criteria to qualify as a
} 
approved list of occupations ${ }^{12}$ is more restrictive than the $\mathrm{H}-1 \mathrm{~B}$, each occupation is associated with college-degree holders. Two free trade agreements signed by then-President Bush on September 3, 2003 set aside 1,400 and 5,400 of the annual H-1B visas (called H-1B1) for citizens of Chile and Singapore, respectively. Another bill signed on May 11, 2005 created 10,500 annual E-3 visas for Australian professionals.

How policy changes have affected the behavior of foreign citizens remains an open question. Collegeeducated workers from Canada, Mexico, Chile, Singapore, and Australia seeking US employment should be largely unaffected by H-1B policy changes. There is no limit to the number of TN visas that can be issued, and the caps on H-1B1 and E-3 visas have never been reached. Thus, workers from those five key countries have viable alternatives to the $\mathrm{H}-1 \mathrm{~B}$ visa and face much lesser constraints in entering the US labor force.

Figure 3 demonstrates that workers from countries with H-1B substitutes indeed choose alternative routes of entry. TN, H-1B1, and E-3 visas have become more popular throughout the period of binding $\mathrm{H}-1 \mathrm{~B}$ limits. Moreover, the percentage of $\mathrm{H}-1 \mathrm{~B}$ visas issued to citizens of these countries peaked at $4.7 \%$ in fiscal year 2003 and has steadily declined to $2.8 \%$ in $2008 .^{13}$

As discussed earlier, we are particularly interested in studying whether policy changes have had an effect on the abilities of foreign students interested in US undergraduate education. We assume that even though high caps were temporary, there was a reasonable expectation of permanence - The trend had been for a rising cap, and the Immigration and Naturalization Service was even forgiven for exceeding the cap in 1999. By Fall 2003, however, it was clear that there would be no renewal. Most international students considering matriculation after that date (i.e., beginning in Fall 2004) would expect limited access to the US labor market. Canadians, Chileans, Mexicans, and Singaporeans were exempt, however, while Australians became exempt the following year (i.e., beginning in Fall 2005). This variation in H-1B policy across countries and time allows us to identify the effects of visa restrictions. ${ }^{14}$

\subsection{Student Ability Data}

We use SAT scores as a measure of applicant ability in spite of recent controversy in doing so. Many university admissions offices stress the importance of alternative criteria to standardized test scores.

TN or H-1B type of worker. Hence, only a nominal number of professional visas are issued to Canadians, despite their significant presence in the US labor force.

${ }^{12}$ See NAFTA appendix 1603.D.1, available at http://www.consular.canada.usembassy.gov/nafta_professions.asp.

${ }^{13}$ Data is from "Non-immigrant visa issuances by visa class and by nationality" at the US Department of State, http://www.travel.state.gov/visa/frvi/statistics/statistics_4396.html.

${ }^{14}$ About $24 \%$ of our sample of prospective students come from one of these five key countries. 
Rask and Tiefenthaler (2009, p. 1) note that "The chief complaint against the SAT is that it is not the best predictor of college success but is highly correlated with parental education and income." For example, high income students might achieve high scores not through ability, but rather by enrolling in private test preparation classes or through repeated exam attempts. Though Rask and Tiefenthaler find that SAT scores are better able to predict college performance for some demographic groups, the magnitude of the effects is not meaningful.

Geiser and Santelices (2007), like Rask and Tiefenthaler (2009), advocate high school grade point average (GPA) as a preferred measure of ability. They use University of California data to perform a multivariate regression of cumulative four-year college GPA on high school GPA, verbal SAT score, and math SAT score. They find that a one standard deviation increase in high school GPA correlates with a 0.36 standard deviation increase in college GPA. A one standard deviation increase in verbal SAT scores correlates with a 0.23 standard deviation increase in college GPA. Math scores were insignificant. Bound, Hershbein, and Long (2009), Rothstein (2004), and Vigdor and Clotfelter (2003) provide additional SAT critiques.

Nonetheless, most SAT critiques focus on its ability to predict domestic student success (or they choose not to distinguish between domestic and international students in the analysis). The SAT for international students is offered less frequently and in more geographically dispersed areas, which should deter strategic test-taking and multiple testing attempts. Many schools that choose not to require the SAT for domestic applicants still require them for international students, pointing to the college admission offices' continued faith in the exam as a primary tool for assessing and comparing the ability of applicants from diverse countries and grading systems. Thus, we argue that the use of the SAT as a measure of applicant quality is probably more justifiable for international students.

Our primary data source is the College Board, which owns and administers the SAT. This dataset provides a sample of foreign-nationals sending SAT score reports to US colleges and universities. These students might ultimately decide against applying to these schools officially. Hence, score reports provide a measure of the quality of prospective students as opposed to actual applicants. ${ }^{15}$ This dataset includes a sample of high-school seniors who took the exam outside the United States between November 2000 and March 2008, dropping those who have dual US citizenship or are permanent US residents. ${ }^{16}$ A student may take the SAT multiple times, but the data only records the math and verbal scores from the last exam that the student has completed. It also includes demographic

\footnotetext{
${ }^{15}$ Thomas (2004b, p. 1375) argues that by "Identifying the set of institutions where college-bound students sent their SAT scores remains the most accurate form of revealed preference at the initial stage of the college-decision path."

${ }^{16} 99 \%$ of score reports come from October, November, December, and January exams. The remaining few come from March and April exams that are only available only in select countries.
} 
information about the student that he/she supplied to the College Board. We do not know the date in which a student requested the exam scores be sent to particular universities, and we assume that they did so at the latest exam date. Each available observation represents a unique score report. Since individual students are likely to send multiple reports from a single exam, the dataset records several observations per student.

We are interested in whether the academic qualifications (SAT scores) of foreigner-nationals interested in US education have changed in response to more restrictive $\mathrm{H}-1 \mathrm{~B}$ policy. The appropriate methodology is to compare the average scores of reports received by US schools before and after the policy change. Unfortunately, information identifying specific schools is not available since the College Board wishes to preserve the institutional privacy of individual schools. Instead, they attached userdefined school characteristics to the dataset. We know four characteristics: The region of the country in which the school is located (as defined by the Bureau of Economic Analysis); the school's funding source (public or private); school type (e.g., research, liberal arts, etc.); and school tier (or quality). We then define "pseudo-schools" by their type, tier, funding, and region. We aggregate individual score-report information accordingly.

School type and tier characteristics are determined by the 2009 US News and World Report Guide to America's Best Colleges (USNWR). USNWR provides a single rank of US colleges and universities that is determined by several criteria including enrollee SAT scores, student/faculty ratio, and academic reputation among peer institutions. It is widely-used by perspective students when choosing a school to attend. ${ }^{17}$ The guide ranks institutions within four types: national research universities, national liberal arts colleges, masters-granting universities, and four-year baccalaureate schools. The ranking structure varies by school type in that the guide ranks masters-granting universities and baccalaureate schools within four geographic regions, whereas research universities and liberal arts colleges are compared nationally. The College Board supplied us with the type and general ranking of schools receiving SAT score reports. For research and liberal arts schools, we know whether a recipient school was ranked in the top 25, between numbers 26-50, between 51-100, other tier 1, tier 3, or tier 4 (there is no explicit tier 2). For the other institutions, we know if they were among the top 10, 11-25, other tier 1 , tier 3 , or tier 4 within their region. We use this to create a harmonized tier structure. We label research and liberal arts schools in the top 50 as "Top Tier," 51-100 and other tier 1 as "Middle Tier," while tier 3 and 4 schools are "Bottom Tier." For masters and baccalaureate schools, we place the 40 top 10 schools in the Top Tier, the 11-25 and other tier 1 institutions in the Middle Tier, and

\footnotetext{
${ }^{17}$ See Griffith and Rask (2007), Webster (2001), and Monks and Ehrenberg (1999) for studies using USNWR and further details about the guide.
} 
the remaining schools in the Bottom Tier. ${ }^{18}$

Summary statistics for individual SAT score reports by type and tier of school are provided in Table 1. Table 2 gives aggregate statistics. Average math, verbal, and total SAT scores were 638, 552, and 1190. Higher quality schools receive better SAT score reports, with the best scores generally going to liberal arts colleges.

For reasons discussed in the Introduction, we supplement our analysis of College Board data with a case study of a highly selective college. Specifically, we were given full access to detailed information on each international applicant to this school, including SAT scores, high school GPA, and other personal characteristics. The data are available from 2001 through 2008. As discussed before, the key advantages of this dataset are the use of standardized high school GPAs as an alternative to SAT scores and the focus on actual applicants as opposed to potential applicants.

\subsection{Main Regression Specification}

Though the theory in Section 3.1 modeled the effects of H-1B visa restrictions on individual decisionmaking, data limitations do not allow direct empirical estimation of individual behavior. The natural experiment methodology would require observation of an individual's interest in US education both before and after the policy change - information that is clearly unavailable. Instead, we can learn about the collective outcomes of individual decisions by measuring the characteristics of the pool of individuals interested in US education before and after the policy. That is, aggregate regressions are more consistent with the natural experiment methodology than individual-level regressions given the data we have.

To identify the effects of $\mathrm{H}-1 \mathrm{~B}$ policy on the abilities of prospective students from abroad, we estimate the simple regression model in Equation (1).

$$
\text { Score }_{s, c, t}=\alpha+\beta \cdot H 1 B_{-} \text {Restriction }_{s, c, t}+\delta_{s}+\delta_{c}+\delta_{t}+\varepsilon_{s, c, t}
$$

The variable Score is our primary measure of the academic quality of international applicants, measured by the average math, verbal, or combined SAT score of reports received by pseudo-school $s$ from students who last took the exam in country $c$ at date $t$. The main coefficient of interest, $\beta$, measures the effect of the restrictive $\mathrm{H}-1 \mathrm{~B}$ visa policy on the quality of foreign students interested in US education. In our baseline regressions, we assume that students taking the SAT in the month

\footnotetext{
${ }^{18}$ Students can and do elect to send reports to non-ranked institutions, such as community colleges and proprietary schools. We choose to focus upon the four school categories ranked in the annual US News and World Report survey of colleges.
} 
following a policy change are aware of that change, and hence take the immigration policy change into consideration when deciding whether to take the SAT and send their scores to a US school. The variable $H 1 B \_$Restriction equals zero for individuals taking the exam on or before October 2003, those from Canada, Chile, Mexico, and Singapore for any year, and those from Australia at all dates except November 2003 through May 2005. The variable equals one for all other observations. This implies that $\beta$ will be negative if current visa policy has reduced the academic qualifications of foreign students interested in US education.

The vector $\delta_{s}$ controls for time-invariant fixed effects specific to particular schools, $\delta_{c}$ does the same for countries, and $\delta_{t}$ represents year effects for the most recent year in which the student took the exam in order to control for macroeconomic trends and common trends in test-taking behavior. $\varepsilon_{i, c, t}$ is an error term. Regressions weight cells by their inferred number of population score reports. ${ }^{19}$

\section{Results}

\subsection{Main Results from College Board Data}

Baseline results are in Table 3. Results for math scores are in columns (1)-(3), verbal scores are in (4)-(6), and total scores are in (7)-(9). Each regression uses year fixed effects. The first specification for each dependent variable includes origin country plus receiving school fixed effects. Standard errors are clustered by country. The second and third instead use school*country fixed effects with standard errors clustered by this unique identifier.

The estimated coefficients on $H 1 B_{-}$Restriction $_{s, c, t}$ when applicant characteristics are not controlled for are negative and statistically significant at least at the 5 percent level except when the average SAT verbal score used as the dependent variable. The size of the estimated coefficients suggests that recent $\mathrm{H}-1 \mathrm{~B}$ visa restrictions have reduced the average math SAT score of foreign prospective students by about 8.5 points, verbal scores by about 10 points, and combined scores by 18.5 points.

To see if the results change when we account for applicant characteristics that might be correlated with their academic quality, we add a variety of applicant characteristics as controls. The results are shown in Columns (3), (6), and (9). Added controls include a school's share of applicants who are sure to apply for financial aid, intend to play intercollegiate sports, and who plan to eventually earn an advanced degree. We also include demographic controls for gender, race, and parental education. ${ }^{20}$

\footnotetext{
${ }^{19}$ The College Board data is an unweighted sample within academic year, but is weighted across years. Each report in the sample corresponds to between 1.4 and 5.3 reports in the population, depending upon the academic year of observation.

${ }^{20}$ See Thomas (2004a) and (2004b) for variables that predict SAT scores for domestic test-takers.
} 
Reassuringly, the sign and size of the estimated coefficients on $H 1 B_{-}$Restriction $_{s, c, t}$ change little and they continue to be statistically significant (in fact, even more significant than without these controls). The only meaningful change in the size of the coefficients concerns the average verbal score, which rises a bit when the additional controls are used.

Webster (1999) argues that SAT scores of enrolled students were the most important determinant of research universities' USNWR rankings in 1999. From his published results, we can infer that a one-point increase in SAT score corresponded to a 0.20 improvement in the rankings. ${ }^{21}$ Using the 2009 USNWR rankings of national research and liberal arts universities, we find that a one-point rise in SAT scores is associated with a 0.29 improvement in the ranking. ${ }^{22}$ If the average score among enrollees were to drop by the same amount as the decline among international prospective students (roughly 20 points), it would be associated with a 4 to 6 place loss in USNWR ranking.

Table 4 presents the OLS estimates of Equation (1) but with log-scores as the dependent variables. Again, the results are robust to this alternative specification, suggesting that restrictive H-1B policy caused prospective student scores to drop by a significant $1.4-1.5 \%$.

\subsection{Timing Issues in Identifying Average Score Effects}

The baseline results of Tables 3 and 4 suggest that US colleges are receiving lower average quality score reports from foreign students as a result of restrictive H-1B visa policy. However, those effects could be subject to a number of timing issues that we consider in this section.

First, we explore potential seasonality in the data. Seasonality could occur, for example, if repeated test attempts result in higher averages than first attempts and are disproportionately represented in particular months. Since our dataset does not identify the number of times an individual has taken the exam, we cannot control for repeated attempts, but we can account for seasonality by controlling for the month and year in which an exam was taken.

The first row of results in columns (1)-(3) of Table 5 repeat the regressions in columns (2), (5), and (8) of Table 3, but replace year indicators with year-by-month exam date fixed effects. The second row of results does this for the natural log regressions of Table 4. One limitation of this approach is that the SAT is not offered to all countries on all potential exam dates. This approach will also reduce variation in the data and decrease the efficiency of estimates. Nonetheless, this robustness check could

\footnotetext{
${ }^{21}$ Webster (1999) uses a sample of 114 research universities. He reports a standard deviation of average SAT scores among enrolled students equal to 129.55 . The correlation between scores and school rank is -0.78 . If schools are ranked from 1 to 114, the standard deviation of rank would be 33, and the slope coefficient would be -0.20 .

${ }^{22}$ As in Webster (1999), this estimate comes from a simple bivariate regression of college rank on the average of first and third quartile SAT scores of enrolled students among institutions reporting SAT scores to USNWR. Our regression produces a coefficient of -0.293 , standard error of 0.013 , and $R^{2}$ of 0.74 . See Figure 4 for a scatterplot of the data.
} 
be important if visa policy changes were correlated with SAT seasonality.

The results for math SAT scores are strikingly similar to those of baseline regressions. Without seasonality controls (Table 3, Column 2), binding visa policy reduced math scores by 8.5 points. With seasonality controls, the estimate increases to a 9.9 point loss. Both methodologies suggest a 1.2-1.4\% decline in math scores when measuring the dependent variable in logs. The effect of policy on verbal scores, by contrast, disappears. This mitigates the total SAT score effect so that restrictive policy reduces scores by 9.8 points (or $0.6 \%$ ).

The robustness of the results for math scores is especially encouraging. One might argue that math scores are a better measure of foreign student ability, while English verbal scores are likely to be a noisier measure of general intellectual ability. For example, those who happen to grow up in an American English speaking environment will probably score high.

Another potential timing issue involves difficulty in identifying the date at which foreign students respond to policy. Baseline results assume that test-takers respond in the month following the policy change. Column (4) of Table 5 instead assumes that test-takers respond in the month of the policy change, whereas column (5) assumes that people respond two months after the policy change. The results do not change much across assumptions, pointing to the robustness of our key result.

Finally, the College Board dataset unfortunately does not measure the date in which a student elects to send a score report to a given school. This is a problem for our results if students who had taken the exam before the policy change then respond to the policy change by selecting a new group of schools to receive reports. Column (6) attempts to address this issue by assuming that people apply to matriculate to universities in the fall of the year following their SAT date. For example, consider individuals taking the SAT in the 2002-03 academic year. Those taking the exam between September and December of 2002 will be applying for Fall 2003 matriculation, while those taking it from January to June 2003 will be applying for Fall 2004. Policy changes will affect those who have not yet matriculated. Thus, a policy change in October 2003 will affect those who took the exam anytime in 2003, as students who tested in the early part of the year can still respond by sending their score reports to alternative schools. Column (6) indicates that the SAT quality response to H-1B policy is again robust to this timing assumption. The combined score drops by more than 13 points.

\subsection{Country Exclusions}

Our theoretical and empirical models implicitly assume that US immigration policy does not affect an individual's reservation wage. Estimation of (1) could be biased if US policy dates are correlated 
with country-specific events or trends. Table 6 explores these potential biases by excluding particular countries that pose particular concern. The empirical specification is as Column 3 of Table 5 Regressions are weighted, cluster-robust, and include exam date fixed effects.

Column 1 considers countries bound by H-1B constraints that experienced unique changes during our period of analysis. First, China and India are undergoing rapid economic development. Second, Bulgaria and Romania signed the Treat of Accession to the European Union in April 2005 and formally joined the EU in January 2007. These developments could possibly deter students from considering US education. For China and India, domestic schooling and employment options may be becoming more attractive. For Bulgaria and Romania, the EU now provides less expensive schooling and greater labor market access. Eliminating these four countries from regressions, however, does not affect qualitative results - coefficient estimates are nearly identical to those of Column 3 in Table 5.

Our results are identified by a natural experiment in which the immigration policy change affects all but five key countries. Roughly two-thirds of score reports among exception countries come from Canadians, and another quarter come from Singaporeans. Columns 2 and 3 omit score reports sent from citizens of these respective countries. Though this affects magnitudes of the estimated coefficients, the qualitative conclusions remain intact.

\subsection{Compositional and Demographic Effects}

The College Board dataset is rich enough that we can explore a number of additional issues surrounding the effects of the restrictive H-1B policy. First, Table 7 assesses whether the effects differ across type and quality of institution. First, policy seems to have been least harmful for research schools, which saw an SAT point drop of just 7.5 points. Liberal Arts and Masters Granting schools, in contrast, saw declines about double that effect. Baccalaureate losses were even larger, though we caution that only $1.6 \%$ of score reports are sent to Baccalaureate institutions. Not surprisingly, elite schools are less harmed by policy than middle and bottom tier institutions. In the final set of results, we differentiate top research schools from all others. The general effect of restrictive policy was to reduce SAT scores of potential students by 14 points. Top Research schools mitigated this decline by a significant 8.4, but still suffered losses.

Table 8 explores policy's effect on the demographic composition of potential applicants. These results might be particularly relevant for institutions who use international students to enhance the diversity of their student body. Column (1) considers gender composition - visa restrictions have had no effect. The next four columns explore racial composition. Restrictive H-1B policy has come 
at the expense of Asian applicants. The share of score reports from international Asian students has decreased by 7.6 percentage points. Whites, in contrast, saw a 5.9 percentage-point increase in applicant share. ${ }^{23}$

The final two specifications address foreign student motives for studying in the US. Column (6) demonstrates that students who need to apply for financial aid are more likely to continue applying for US education after the policy change. Column (7) shows that those intending to continue their education after obtaining a bachelors degree have not been deterred by restrictive H-1B policy. This is not at all surprising, given that their motive for US study is not to enter the US labor force, but rather to pursue an advanced degree. These students would not want or need an H-1B visa to matriculate at a graduate school. Moreover, those with advanced graduate degrees (such as a Ph.D.) who find eventual employment at academic institutions are exempt from $\mathrm{H}-1 \mathrm{~B}$ quotas. $^{24}$

While baseline results effectively established that average ability declines in response to visa policy restrictions, they are not informative about the parts of the ability distribution most affected. To analyze this issue we first divide score reports into quintiles of the ability distribution of the prebinding policy period (exams taken on or before Spring 2003). We then calculate the number and share of a pseudo-school's reports from country $c$ at time $t$ belonging to each quintile. ${ }^{25}$ Finally, we regress these variables, by quintile, on the policy variable (also including the usual array of fixed effects and clustered standard errors).

The first row of Table 9 identifies the effects for quintile shares. The consequences of policy are particularly severe at the tails of the ability distribution. The proportion of lowest-ability score reports declined 1.5 percentage points, while the proportion of highest-ability reports dropped 3.2 percentage points. Both results are consistent with the theory illustrated in Figure 2a.

The decline in average SAT scores, as well as the decline in the proportion of highest-quintile applicants, can come from two sources: a decrease in the numerator or an increase in the denominator. That is, averages could be declining due either to a fall in high ability applicants or to a proliferation of score reports among weak students. From an admissions officer's or policy-maker's standpoint, the former explanation would be far more concerning than the latter. Although the decline in the proportion of lowest-ability students argues against the proliferation of weak applications, we can gain more insight from the second row of results in Table 9 where the dependent variable is the number of score reports received by a pseudo-school from country $c$ at time $t$ in each quintile. These results

\footnotetext{
${ }^{23}$ In interpreting these coefficients, recall that regressions already control for country of origin (by school) fixed effects. Thus, racial composition effects are driven by variation of application rates of students within countries.

${ }^{24}$ In addition, professors and researchers sometimes qualify for H-1B alternatives, including the EB-1 visa.

${ }^{25}$ For simplicity, we drop reports for the $1 \%$ of exams taken during March and April.
} 
uphold the interpretation that restrictive policy is deterring high-ability foreign students from applying to US universities, though estimates are somewhat imprecise. Schools in each period are receiving 18 fewer top-quintile score reports from each country bound by restrictive H-1B policy. Given that the weighted average number of top-quintile reports received (from country $c$ at time $t$ ) is just 32, this magnitude is quite large.

\subsection{Case Study}

The College Board data presents three problems. First, it provides only one measure of ability - SAT scores - which some researchers consider an inferior measure of applicant ability as compared to high school GPA (though these critiques are usually aimed at evaluations of domestic applicants). Second, the College Board data cannot be strictly interpreted as a sample of foreign applicants, but is rather a sample of foreign prospective applicants. This is because it includes both applicants and those who sent SAT scores to US schools but later declined to submit a formal and complete application. We cannot distinguish between these two groups of individuals in the College Board data. Third, results may be confounded by remaining timing issues including the challenge of precisely identifying the dates in which individual behavior would respond to a policy change.

Our second dataset is assembled to account for these three problems. It includes every foreignnational officially applying to matriculate at a particular highly-selective university between Fall 2001 and Fall 2008. ${ }^{26}$ The use of the applicant data (as opposed to the College Board's prospective student data) reduces ambiguity surrounding the timing of international applicants' awareness of H-1B policy changes since students should be aware of the current policy at the time of application submission. ${ }^{27}$ Finally, the dataset also includes a measure of high school GPA. Raw GPAs would be greatly confounded by grading system differences across countries. Fortunately, this university's admissions office - using their long experience with overseas high schools - resolved this issue by converting raw values into an internationally comparable GPA measured on a four point scale. Values therefore represent GPAs that this university uses to evaluate international applicants.

Our regression methodology is similar to the specification in (1). The dependent variables now reflect the average abilities of applicants to this particular university. Observations vary by country of origin $(c)$ and year of application $(t)$. The model includes both country and year fixed effects

\footnotetext{
${ }^{26}$ As in the case of the College Board data, we drop individuals who have dual US citizenship or are permanent US residents.

${ }^{27}$ For example, we assume that all international students applying to matriculate in Fall 2004 did so with awareness of the H-1B policy change in October 2003. Although some applications were received in late summer 2003, the application deadline was in January 2004.
} 
but obviously omits institutional controls. Regressions weight observations by the total number of applicants from country $c$ at year $t$, and standard errors are clustered by country. For the policy variable, we now assume that students perceived H-1B policy to be non-binding if they applied to enter college before 2004, if they applied from Canada, Chile, Mexico, and Singapore in any year, or if they were Australian applying to enter college in any year except 2004.

Table 10 provides results for dependent variables measured in both levels and logs. As in the prospective applicant regressions controlling for seasonality, the policy effects are again most prominent for math scores. Column (1) demonstrates that the math SAT scores of applicants from countries subject to binding $\mathrm{H}-1 \mathrm{~B}$ constraints have declined by 13 points relative to the scores among applicants from countries who have $\mathrm{H}-1 \mathrm{~B}$ alternatives. Measured in logs, this suggests a $2.2 \%$ decline in average ability of international applicants. For overall SAT scores, in contrast, the estimate is negative but not statistically different from zero. This may be due to sample size, which is much smaller than with the College Board dataset. It is worth emphasizing that the point estimates of the total score penalty in percentage terms is quite similar in the two samples. For prospective international applicants, H-1B restrictions reduced total scores by about 1.5\%. For this university's actual applicants, scores reduced by $1.2 \%$.

Perhaps most importantly, Column (4) presents the results using high school GPA. We again see evidence that restrictive $\mathrm{H}-1 \mathrm{~B}$ policy is reducing the quality of international applicants. The average GPA of international applicants at this university declined by 0.09 points, or $2.8 \%$ when measured in $\operatorname{logs}$ - a magnitude higher than that of any of the SAT regressions. The estimated effects on average GPA of restrictive H-1B policy are statistically significant at the $5 \%$ level.

\section{Conclusion}

To our knowledge, this paper is the first to provide rigorous evidence on the effects of restrictive immigration policy on the quality of international applicants to US tertiary education. The analysis employed two datasets: (i) College Board data on the SAT scores of prospective students; and (ii) SAT and GPA data on a highly-selective university's foreign-applicant pool. Both cases generate robust evidence that restrictive policy is reducing the ability (or quality) of foreign students considering US education.

Many US colleges and universities benefit from the presence of high-quality international students directly and indirectly. For example, classroom experience for domestic students is often enriched by the presence of well-motivated and well-prepared international students who provide diversity. 
Universities and their students therefore suffer an immediate consequence of restrictive immigration policy. Should our results translate into lower quality foreign-born graduates, however, the US could face even more important macroeconomic consequences. Many international students continue to work in the US after graduation. Such individuals have proven to be especially effective in innovative and entrepreneurial activity, boosting aggregate productivity. With lower ability individuals seeking entry into the US, the country may ultimately sacrifice those aggregate gains.

Given recent political developments in public opinion regarding highly-educated immigrants, it is increasingly important to design policy to maximize the benefit of skill-based immigration. To this end, our finding suggests that the current H-1B immigration policy (as compared to the policy prior to 2003) may be too restrictive and is deterring the "best and brightest" of the global talent pool from entering the US. Thus, current policy is failing to maximize the benefit of skill-based immigration that the majority of the public tend to favor. 


\section{References}

Bhagwati, Jagdish and Milind Rao (1999) "Foreign Students in Science and Engineering Ph.D. Programs: An Alien Invasion or Brain Gain?" in B. Lindsay Lowell ed., Foreign Temporary Workers in America: Policies that Benefit the U.S. Economy, Quorum Books, Westport, CT.

Borjas, George J. (1987) "Self-Selection and the Earnings of Immigrants" The American Economic Review, 77(4) 531-553.

Borjas, George J. (1999) Heaven's Door. Princeton University Press, Princeton and Oxford.

Borjas, George J. (2002) "An Evaluation of the Foreign Student Program" John F. Kennedy School of Government, Harvard University, Faculty Research Working Paper RWP02-026.

Borjas, George J. (2006) "Immigration in High-Skill Labor Markets: The Impact of Foreign Students on the Earnings of Doctorates" NBER Working Paper \#12085.

Borjas, George J. (2007) "Do Foreign Students Crowd Out Native Students from Graduate Programs?" in Paula E. Stephan and Ronald G. Ehrenberg eds., Science and the University, University of Wisconsin Press.

Bound, John, Brad Hershbein, and Bridget Terry Long (2009) "Playing the Admissions Game: Student Reactions to Increasing College Competition” NBER Working Paper 15272.

CBS News/New York Times Poll (2007), May 18-23.

Chellaraj, Gnanaraj, Keith E. Maskus, and Aaditya Mattoo (2005) "The Contribution of Skilled Immigration and International Graduate Students to U.S. Innovation." World Bank Policy Research Working Paper 3588.

Chen, Yiu Por (2005) "Skill-Sorting, Self-Selectivity, and Immigration Policy Regime Change: Two Surveys of Chinese Graduate Students' Intention to Study Abroad" AEA Papers and Proceedings, 95 (2), 66-70.

Chiswick, Barry R. (1999) "Policy Analysis of Foreign Student Visas" in B. Lindsay Lowell ed., Foreign Temporary Workers in America: Policies that Benefit the U.S. Economy, Quorum Books, Westport, CT.

Chiswick, Barry R. (2000) "Are Immigrants Favorably Self-Selected? An Economic Analysis" IZA Discussion Paper No. 131. 
Clark, Ximena, Timothy J. Hatton, and Jeffrey G. Williamson (2007) "Explaining US Immigration, 1971-1998" The Review of Economics and Statistics, 89(2), 359-373.

College Board. Derived data provided by the College Board. Copyright 2000-2008 The College Board. www.collegeboard.com.

Freeman, Richard B. (2009) "What Does Global Expansion of Higher Education Mean for the US?" NBER Working Paper 14962.

Geiser, Saul and Maria Veronica Santelices (2007) "Validity of High-School Grades in Predicting Student Success Beyond the Freshman Year: High-School Record vs. Standardized Tests as Indicators of Four-Year College Outcomes" Center for Studies in Higher Education, Research \& Occasional Paper Series: CSHE.6.07.

Griffith, Amanda and Kevin Rask (2007) "The Influence of the US News $\&$ World Report Collegiate Rankings on the Matriculation Decision of High-Ability Students: 1995-2004" Economics of Education Review, 26, 244-255.

Hira, Ron (2007) "Outsourcing America's Technology and Knowledge Jobs: High-Skill Guest Worker Visas are Currently Hurting Rather than Helping Keep Jobs at Home" Economic Policy Institute Briefing Paper 187.

Hainmueller, Jens and Michael J. Hiscox (2010) "Attitudes toward Highly Skilled and Low-skilled Immigration: Evidence from a Survey Experiment" American Political Science Review, 104, 61-84.

Hunt, Jennifer (2009) "Which Immigrants are Most Innovative and Entrepreneurial? Distinctions by Entry Visa" NBER Working Paper 14920.

Hunt, Jennifer and Marjolaine Gauthier-Loiselle, (2009). "How Much Does Immigration Boost Innovation?," CEPR Working Paper 7116.

Kapur, Devesh and John McHale (2005) Give Us Your Best and Brightest: The Global Hunt for Talent and Its Impact on the Developing World. Center for Global Development. Washington, DC.

Kerr, William R. and William F. Lincoln (2008) "The Supply Side of Innovation: H-1B Visa Reforms and US Ethnic Invention” Harvard Business School Working Paper 09-005.

Levin, Sharon G., Grant C. Black, Anne E. Winkler, and Paula E. Stephan (2004) "Differential Employment Patterns for Citizens and Non-Citizens in Science and Engineering in the United States: Minting and Competitive Effects" Growth and Change, 35 (4), 456-475. 
Mayr, Karin and Giovanni Peri (2009) "Brain Drain and Brain Return: Theory and Application to Eastern-Western Europe" The B.E. Journal of Economic Analysis 63 Policy, 9(1), Article 49.

Mayda, Anna Maria (2009) "International Migration: A Panel Data Analysis of the Determinants of Bilateral Flows" Journal of Population Economics, forthcoming.

Miano, John (2007) "Low Salaries for Low Skills: Wages and Skill Levels for H-1B Computer Workers, 2005" Center for Immigration Studies Backgrounder.

Monks, James and Ronald G. Ehrenberg (1999) "The Impact of US News 8 World Report College Rankings on Admissions Outcomes and Pricing Policies at Selective Private Institutions" NBER Working Paper 7227.

Peri, Giovanni and Chad Sparber (2008) "Highly Educated Immigrants and Native Occupational Choice." CReAM Working Paper \#07/08, November 2008.

Preston, Julia (2010) "Work Force Fueled by Highly Skilled Immigrants" The New York Times, April 15.

Rask, Kevin and Jill Tiefenthaler (2009) "The SAT as a Predictor of College Success: Evidence from a Selective University" mimeo, Wake Forest University.

Rosenzweig, Mark (2006) "Global Wage Differences and International Student Flows" Brookings Trade Forum.

Sjaastad, Larry A. (1962) "The Costs and Returns of Human Migration" Journal of Political Economy, 87(Suppl.) S7-S36.

Stephan, Paula E. and Sharon G. Levin (2007) "Foreign Scholars in U.S. Science: Contributions and Costs" in Paula E. Stephan and Ronald G. Ehrenberg eds., Science and the University, University of Wisconsin Press.

Thomas, M. Kathleen (2004a) "Seeking Every Advantage: The Phenomenon of Taking Both the SAT and ACT" Economics of Education Review, 23, 203-208.

Thomas, M. Kathleen (2004b) "Where College-Bound Students Send Their SAT Scores: Does Race Matter?" Social Science Quarterly, 85(5), 1374-1389.

US State Department. "Immigrant Visa Statistics" Website: http://travel.state.gov/visa/frvi/statistics/statistics_ 
US State Department. "Temporary Workers” Website: http://travel.state.gov/visa/temp/types/types_1271.html.

Vigdor, Jacob L. and Charles T. Clotfelter (2003) "Retaking the SAT" The Journal of Human Resources, 38(1), 1-33.

Webster, Thomas J. (2001) "A Principal component analysis of the US News \& World Report Tier Rankings of Colleges and Universities" Economics of Education Review, 20, 235-244. 
Table 1: Average SAT Scores of Potential International Applicants by Type and Tier of School

\begin{tabular}{|c|c|c|c|c|c|c|c|c|c|}
\hline \multirow{2}{*}{\multicolumn{2}{|c|}{\begin{tabular}{|c|} 
Harmonized Tier \\
Within-Type Tier
\end{tabular}}} & \multicolumn{3}{|c|}{ Top Tier } & \multicolumn{3}{|c|}{ Middle Tier } & \multicolumn{2}{|c|}{ Bottom Tier } \\
\hline & & Top 10 & Top 25 & 26 to 50 & 11 to 25 & 51 to 100 & Other Tier 1 & Tier 3 & Tier 4 \\
\hline \multirow[t]{3}{*}{ Research } & Mean & & 1280 & 1200 & & 1128 & 1084 & 1055 & 1010 \\
\hline & Std Dev & & 161 & 162 & & 163 & 172 & 175 & 176 \\
\hline & Obs & & 38061 & 17404 & & 13638 & 3696 & 3452 & 2909 \\
\hline \multirow[t]{3}{*}{ Liberal Arts } & Mean & & 1260 & 1216 & & 1143 & 1129 & 1081 & 970 \\
\hline & Std Dev & & 157 & 157 & & 164 & 167 & 172 & 201 \\
\hline & Obs & & 7940 & 3603 & & 2027 & 628 & 769 & 363 \\
\hline \multirow[t]{3}{*}{ Masters } & Mean & 1099 & & & 1054 & & 1034 & 1002 & 1012 \\
\hline & Std Dev & 160 & & & 174 & & 178 & 182 & 193 \\
\hline & Obs & 2694 & & & 1359 & & 3014 & 1821 & 1133 \\
\hline \multirow[t]{3}{*}{ B accalaureate } & Mean & 1076 & & & 1016 & & 966 & 1017 & 952 \\
\hline & Std Dev & 196 & & & 179 & & 194 & 188 & 209 \\
\hline & Obs & 491 & & & 302 & & 338 & 232 & 317 \\
\hline
\end{tabular}

Note: Summary statistics of individual score reports sent by international SAT test-takers in academic years 2000-01 through 2007-08. Source: College Board sample data. 
Table2: Descriptive Statistics, College Board SAT Data

\begin{tabular}{|c|c|c|c|c|c|}
\hline Variable & Obsservations & Mean & Std. Dev. & Min & Max \\
\hline SAT Math Score & 106191 & 638 & 110 & 200 & 800 \\
\hline SAT Verbal Score & 106191 & 552 & 106 & 200 & 800 \\
\hline SAT Total Score & 106191 & 1190 & 189 & 410 & 1600 \\
\hline Female & 106180 & 0.466 & 0.499 & 0 & 1 \\
\hline Intends to Play Intercollegiate Sports & 106191 & 0.289 & 0.453 & 0 & 1 \\
\hline Sure to Apply for Aid & 96293 & 0.601 & 0.490 & 0 & 1 \\
\hline Ultimately Wants Advanced Degree & 95410 & 0.735 & 0.442 & 0 & 1 \\
\hline Bound by H-1B Visa Cap & 106191 & 0.526 & 0.499 & 0 & 1 \\
\hline Asian & 100924 & 0.490 & 0.500 & 0 & 1 \\
\hline Black & 100924 & 0.097 & 0.295 & 0 & 1 \\
\hline Hispanic & 100924 & 0.074 & 0.262 & 0 & 1 \\
\hline Other Non-White Race & 100924 & 0.118 & 0.323 & 0 & 1 \\
\hline White & 100924 & 0.221 & 0.415 & 0 & 1 \\
\hline Mother's Edu: Less than High School Degree & 91777 & 0.062 & 0.241 & 0 & 1 \\
\hline Mother's Edu: HS Diploma & 91777 & 0.121 & 0.326 & 0 & 1 \\
\hline Mother's Edu: Business School & 91777 & 0.025 & 0.158 & 0 & 1 \\
\hline Mother's Edu: Some College or Assoc. Degree & 91777 & 0.141 & 0.348 & 0 & 1 \\
\hline Mother's Edu: Bachelor's Degree & 91777 & 0.356 & 0.479 & 0 & 1 \\
\hline Mother's Edu: Graduate Degree & 91777 & 0.295 & 0.456 & 0 & 1 \\
\hline Father's Edu: Less than High School Degree & 91652 & 0.046 & 0.209 & 0 & 1 \\
\hline Father's Edu: HS Diploma & 91652 & 0.065 & 0.246 & 0 & 1 \\
\hline Father's Edu: Business School & 91652 & 0.031 & 0.173 & 0 & 1 \\
\hline Father's Edu: Some College or Assoc. Degree & 91652 & 0.085 & 0.279 & 0 & 1 \\
\hline Father's Edu: Bachelor's Degree & 91652 & 0.318 & 0.466 & 0 & 1 \\
\hline Father's Edu: Graduate Degree & 91652 & 0.455 & 0.498 & 0 & 1 \\
\hline Research University & 106191 & 0.745 & 0.436 & 0 & 1 \\
\hline Liberal Arts College & 106191 & 0.144 & 0.351 & 0 & 1 \\
\hline Masters-Granting University & 106191 & 0.094 & 0.292 & 0 & 1 \\
\hline Baccalaureate School & 106191 & 0.016 & 0.125 & 0 & 1 \\
\hline College Rank: Top Tier (Harmonized) & 106191 & 0.661 & 0.473 & 0 & 1 \\
\hline College Rank: Middle Tier (Harmonized) & 106191 & 0.235 & 0.424 & 0 & 1 \\
\hline College Rank: Bottom Tier (Harmonized) & 106191 & 0.104 & 0.305 & 0 & 1 \\
\hline Private University & 106191 & 0.694 & 0.461 & 0 & 1 \\
\hline College Location: New England & 106191 & 0.223 & 0.416 & 0 & 1 \\
\hline College Location: Middle Atlantic & 106191 & 0.282 & 0.450 & 0 & 1 \\
\hline College Location: Great Lakes & 106191 & 0.127 & 0.333 & 0 & 1 \\
\hline College Location: Plains State & 106191 & 0.035 & 0.184 & 0 & 1 \\
\hline College Location: Southeast & 106191 & 0.132 & 0.339 & 0 & 1 \\
\hline College Location: Southwest & 106191 & 0.038 & 0.191 & 0 & 1 \\
\hline College Location: Rocky Mountain & 106191 & 0.008 & 0.089 & 0 & 1 \\
\hline College Location: Far West & 106191 & 0.155 & 0.362 & 0 & 1 \\
\hline
\end{tabular}

Note: Summary statistics of individual score reports sent by international SAT test-takers in academic years 2000-01 through 2007-08. Source: College Board sample data. 
Table 3: Baseline Results, College Board Data

\begin{tabular}{|c|c|c|c|c|c|c|c|c|c|}
\hline & (1) & (2) & (3) & (4) & (5) & (6) & (7) & (8) & (9) \\
\hline Dependent Variable: & \multicolumn{3}{|c|}{ Math SAT Score } & \multicolumn{3}{|c|}{ Verbal SAT Score } & \multicolumn{3}{|c|}{ Total SAT Score } \\
\hline Bound by H-1B Visa Cap & $\begin{array}{c}-8.503 \\
(4.229)^{* *}\end{array}$ & $\begin{array}{c}-8.408 \\
(2.173)^{* *}\end{array}$ & $\begin{array}{c}-7.617 \\
(1.840)^{* * *}\end{array}$ & $\begin{array}{r}-10.007 \\
(7.010)\end{array}$ & $\begin{array}{c}-9.840 \\
0.381 * * *\end{array}$ & $\begin{array}{l}-12.325 \\
\text { (2. } 244)^{* * *}\end{array}$ & $\begin{array}{l}-18.510 \\
(6,200) * * *\end{array}$ & $\begin{array}{c}-18.248 \\
(3.230) * * *\end{array}$ & $\begin{array}{c}-19.942 \\
(3.109)^{* * *}\end{array}$ \\
\hline$\%$ Sure to Apply for Aid & & & $\begin{array}{c}13.644 \\
(1.570)^{* * *}\end{array}$ & & & $\begin{array}{c}14.384 \\
(1.880)^{* * *}\end{array}$ & & & $\begin{array}{c}28.029 \\
(2.861)^{* * *}\end{array}$ \\
\hline$\%$ Intent to Play Intercollegiate Sports & & & $\begin{array}{c}0.348 \\
(1.662)\end{array}$ & & & $\begin{array}{c}-7.448 \\
(1.733)^{* * *}\end{array}$ & & & $\begin{array}{c}-7.100 \\
(2.897)^{* *}\end{array}$ \\
\hline$\%$ Female & & & $\begin{array}{c}-26.337 \\
(1.539)^{* * *}\end{array}$ & & & $\begin{array}{c}3.897 \\
(1.687)^{* *}\end{array}$ & & & $\begin{array}{c}-22.439 \\
(2.688)^{* * *}\end{array}$ \\
\hline$\%$ Asian & & & $\begin{array}{c}47.155 \\
(3.147)^{* * *}\end{array}$ & & & $\begin{array}{c}-22.539 \\
(3.730)^{* * *}\end{array}$ & & & $\begin{array}{c}24.616 \\
(5.575)^{* * *}\end{array}$ \\
\hline$\%$ Black & & & $\begin{array}{c}-19.716 \\
(4.686)^{* * *}\end{array}$ & & & $\begin{array}{c}-30.511 \\
(4.248)^{* * *}\end{array}$ & & & $\begin{array}{c}-50.227 \\
(7.925)^{* * *}\end{array}$ \\
\hline$\%$ Hispanic & & & $\begin{array}{c}-25.339 \\
(4.629)^{* * *}\end{array}$ & & & $\begin{array}{c}-24.383 \\
(4.495)^{* * *}\end{array}$ & & & $\begin{array}{c}-49.722 \\
(7.822)^{* * *}\end{array}$ \\
\hline$\%$ Other Non-White Race & & & $\begin{array}{c}2.078 \\
(3.400)\end{array}$ & & & $\begin{array}{c}-26.713 \\
(3.599)^{* * *}\end{array}$ & & & $\begin{array}{c}-24.635 \\
(6.010)^{* * *}\end{array}$ \\
\hline$\%$ Ultimately Wants Advanced Degree & & & $\begin{array}{c}17.592 \\
(1.680)^{* * *}\end{array}$ & & & $\begin{array}{c}17.308 \\
(1.856)^{* * *}\end{array}$ & & & $\begin{array}{c}34.900 \\
(3.029)^{* * *}\end{array}$ \\
\hline Mother's Edu: \% HS DIPLOMA & & & $\begin{array}{c}-7.149 \\
(3.616)^{* *}\end{array}$ & & & $\begin{array}{c}13.395 \\
(4.399)^{* * *}\end{array}$ & & & $\begin{array}{c}6.246 \\
(6.891)\end{array}$ \\
\hline Mother's Edu: \% BUSINESS SCHOOL & & & $\begin{array}{c}-16.993 \\
(5.133)^{* * *}\end{array}$ & & & $\begin{array}{c}18.339 \\
(5.810)^{* * *}\end{array}$ & & & $\begin{array}{l}1.345 \\
(9.532)\end{array}$ \\
\hline Mother's Edu: \% SOME COLLEGE or ASSOC & & & $\begin{array}{l}-3.355 \\
(3.448)\end{array}$ & & & $\begin{array}{c}17.518 \\
(4.488)^{* * *}\end{array}$ & & & $\begin{array}{c}14.163 \\
(6.641)^{* *}\end{array}$ \\
\hline Mother's Edu: \% BACHELORS DEGREE or SOME GRAD & & & $\begin{array}{c}2.769 \\
(3.246)\end{array}$ & & & $\begin{array}{c}27.635 \\
(4.118)^{* * *}\end{array}$ & & & $\begin{array}{c}30.404 \\
(6.182)^{* * *}\end{array}$ \\
\hline Mother's Edu: \% GRAD DEGREE & & & $\begin{array}{c}2.503 \\
(3.519)\end{array}$ & & & $\begin{array}{c}29.630 \\
(4.364)^{* * *}\end{array}$ & & & $\begin{array}{c}32.133 \\
(6.650)^{* * *}\end{array}$ \\
\hline Father's Edu: \% HS DIPLOMA & & & $\begin{array}{c}1.712 \\
(4.048)\end{array}$ & & & $\begin{array}{c}0.725 \\
(4.886)\end{array}$ & & & $\begin{array}{c}2.438 \\
(7.748)\end{array}$ \\
\hline Father's Edu: \% BUSINESS SCHOOL & & & $\begin{array}{c}1.270 \\
(4.786)\end{array}$ & & & $\begin{array}{c}20.126 \\
(5.763)^{* * *}\end{array}$ & & & $\begin{array}{c}21.396 \\
(8.875)^{* *}\end{array}$ \\
\hline Father's Edu: \% SOME COLLEGE or ASSOC & & & $\begin{array}{c}10.280 \\
(3.915)^{* * *}\end{array}$ & & & $\begin{array}{c}8.470 \\
(4.692)^{*}\end{array}$ & & & $\begin{array}{c}18.750 \\
(7.376)^{* *}\end{array}$ \\
\hline Father's Edu: \% BACHELORS DEGREE or SOME GRAD & & & $\begin{array}{c}22.387 \\
(3.598)^{* * *}\end{array}$ & & & $\begin{array}{c}21.574 \\
(4.273)^{* * *}\end{array}$ & & & $\begin{array}{c}43.961 \\
(6.685)^{* * *}\end{array}$ \\
\hline Father's Edu: \% GRAD DEGREE & & & $\begin{array}{c}25.834 \\
(3.593)^{* * *}\end{array}$ & & & $\begin{array}{c}38.254 \\
(4.184)^{* * *}\end{array}$ & & & $\begin{array}{c}64.088 \\
(6.597)^{* * *}\end{array}$ \\
\hline Additional Fixed Effects: & $\begin{array}{c}\text { Year } \\
\text { School } \\
\text { Country }\end{array}$ & \multicolumn{2}{|c|}{$\begin{array}{c}\text { Year } \\
\text { School*Country }\end{array}$} & $\begin{array}{c}\text { Year } \\
\text { School } \\
\text { Country }\end{array}$ & \multicolumn{2}{|c|}{$\begin{array}{c}\text { Year } \\
\text { School*Country }\end{array}$} & $\begin{array}{c}\text { Year } \\
\text { School } \\
\text { Country }\end{array}$ & $\begin{array}{r}Y \\
\text { School }\end{array}$ & $\begin{array}{l}\text { ear } \\
\text { Country }\end{array}$ \\
\hline Observations & 36218 & 36218 & 30797 & 36218 & 36218 & 30797 & 36218 & 36218 & 30797 \\
\hline R-squared & 0.58 & 0.68 & 0.72 & 0.4 & 0.52 & 0.56 & 0.54 & 0.64 & 0.69 \\
\hline $\begin{array}{l}\text { Robust standard errors in parentheses } \\
* \text { significant at } 10 \% ; * * \text { significant at } 5 \% ; * * * \text { signific }\end{array}$ & & & & & & & & & \\
\hline
\end{tabular}

Note: Unit of observation is pseudo-school*country-of-origin*year. Regressions are weighted by population number of score reports. Standard errors are clustered by pseudo-school*country-of-origin cells. 
Table 4: Baseline Results, Dependent Variables Measured in Logs

\begin{tabular}{|c|c|c|c|c|c|c|c|c|c|}
\hline \multirow{2}{*}{$\begin{array}{l}\text { Dependent Variable: } \\
\text { Bound by H-1B Visa Cap }\end{array}$} & (1) & (2) & (3) & (4) & (5) & (6) & (7) & (8) & (9) \\
\hline & \multicolumn{3}{|c|}{ In(Math SAT Score) } & \multicolumn{3}{|c|}{ In(Verbal SAT Score) } & \multicolumn{3}{|c|}{ In(Total SAT Score) } \\
\hline Bound by H-1B Visa Cap & $\begin{array}{c}-0.012 \\
(0.007)^{*}\end{array}$ & $\begin{array}{c}-0.012 \\
(0.003)^{* * *}\end{array}$ & $\begin{array}{c}-0.011 \\
(0.003)^{* * *}\end{array}$ & $\begin{array}{l}-0.016 \\
(0.014)\end{array}$ & $\begin{array}{c}-0.016 \\
(0.004)^{* * *}\end{array}$ & $\begin{array}{c}-0.021 \\
(0.004)^{* * *}\end{array}$ & $\begin{array}{c}-0.014 \\
(0.006)^{* *}\end{array}$ & $\begin{array}{c}-0.014 \\
(0.003)^{* * *}\end{array}$ & $\begin{array}{c}-0.015 \\
(0.003)^{* * *}\end{array}$ \\
\hline$\%$ Sure to Apply for Aid & & & $\begin{array}{c}0.023 \\
(0.003)^{* * *}\end{array}$ & & & $\begin{array}{c}0.027 \\
(0.004)^{* * *}\end{array}$ & & & $\begin{array}{c}0.024 \\
(0.003)^{* * *}\end{array}$ \\
\hline$\%$ Intent to Play Intercollegiate Sports & & & $\begin{array}{c}0.001 \\
(0.003)\end{array}$ & & & $\begin{array}{c}-0.012 \\
(0.003)^{* * *}\end{array}$ & & & $\begin{array}{c}-0.005 \\
(0.003)^{* *}\end{array}$ \\
\hline$\%$ Female & & & $\begin{array}{c}-0.044 \\
(0.003)^{* * *}\end{array}$ & & & $\begin{array}{c}0.008 \\
(0.003)^{* * *}\end{array}$ & & & $\begin{array}{c}-0.019 \\
(0.002)^{* * *}\end{array}$ \\
\hline$\%$ Asian & & & $\begin{array}{c}0.075 \\
(0.005)^{* * *}\end{array}$ & & & $\begin{array}{c}-0.043 \\
(0.007)^{* * *}\end{array}$ & & & $\begin{array}{c}0.021 \\
(0.005)^{* * *}\end{array}$ \\
\hline$\%$ Black & & & $\begin{array}{c}-0.039 \\
(0.009)^{* * *}\end{array}$ & & & $\begin{array}{c}-0.058 \\
(0.008)^{* * *}\end{array}$ & & & $\begin{array}{c}-0.047 \\
(0.007)^{* * *}\end{array}$ \\
\hline$\%$ Hispanic & & & $\begin{array}{c}-0.044 \\
(0.008)^{* * *}\end{array}$ & & & $\begin{array}{c}-0.044 \\
(0.009)^{* * *}\end{array}$ & & & $\begin{array}{c}-0.044 \\
(0.007)^{* * *}\end{array}$ \\
\hline$\%$ Other Non-White Race & & & $\begin{array}{c}0.000 \\
(0.006)\end{array}$ & & & $\begin{array}{c}-0.051 \\
(0.007)^{* * *}\end{array}$ & & & $\begin{array}{c}-0.023 \\
(0.005)^{* * *}\end{array}$ \\
\hline$\%$ Ultimately Wants Advanced Degree & & & $\begin{array}{c}0.030 \\
(0.003)^{* * *}\end{array}$ & & & $\begin{array}{c}0.033 \\
(0.004)^{* * *}\end{array}$ & & & $\begin{array}{c}0.032 \\
(0.003)^{* * *}\end{array}$ \\
\hline Mother's Edu: \% HS DIPLOMA & & & $\begin{array}{c}-0.011 \\
(0.006)^{*}\end{array}$ & & & $\begin{array}{c}0.028 \\
(0.009)^{* * *}\end{array}$ & & & $\begin{array}{c}0.007 \\
(0.006)\end{array}$ \\
\hline Mother's Edu: \% BUSINESS SCHOOL & & & $\begin{array}{c}-0.028 \\
(0.009)^{* * *}\end{array}$ & & & $\begin{array}{c}0.035 \\
(0.012)^{* * *}\end{array}$ & & & $\begin{array}{c}0.000 \\
(0.009)\end{array}$ \\
\hline Mother's Edu: \% SOME COLLEGE or ASSOC & & & $\begin{array}{l}-0.004 \\
(0.006)\end{array}$ & & & $\begin{array}{c}0.034 \\
(0.009)^{* * *}\end{array}$ & & & $\begin{array}{c}0.014 \\
(0.006)^{* *}\end{array}$ \\
\hline Mother's Edu: \% BACHELORS DEGREE or SOME GRAD & & & $\begin{array}{c}0.005 \\
(0.006)\end{array}$ & & & $\begin{array}{c}0.054 \\
(0.008)^{* * *}\end{array}$ & & & $\begin{array}{c}0.027 \\
(0.006)^{* * *}\end{array}$ \\
\hline Mother's Edu: \% GRAD DEGREE & & & $\begin{array}{c}0.005 \\
(0.006)\end{array}$ & & & $\begin{array}{c}0.057 \\
(0.009)^{* * *}\end{array}$ & & & $\begin{array}{c}0.029 \\
(0.006)^{* * *}\end{array}$ \\
\hline Father's Edu: \% HS DIPLOMA & & & $\begin{array}{c}0.005 \\
(0.008)\end{array}$ & & & $\begin{array}{l}-0.001 \\
(0.010)\end{array}$ & & & $\begin{array}{c}0.004 \\
(0.007)\end{array}$ \\
\hline Father's Edu: \% BUSINESS SCHOOL & & & $\begin{array}{c}0.005 \\
(0.009)\end{array}$ & & & $\begin{array}{c}0.037 \\
(0.011)^{* * *}\end{array}$ & & & $\begin{array}{c}0.020 \\
(0.008)^{* *}\end{array}$ \\
\hline Father's Edu: \% SOME COLLEGE or ASSOC & & & $\begin{array}{c}0.020 \\
(0.007)^{* * *}\end{array}$ & & & $\begin{array}{c}0.014 \\
(0.009)\end{array}$ & & & $\begin{array}{c}0.018 \\
(0.007)^{* * *}\end{array}$ \\
\hline Father's Edu: \% BACHELORS DEGREE or SOME GRAD & & & $\begin{array}{c}0.043 \\
(0.007)^{* * *}\end{array}$ & & & $\begin{array}{c}0.042 \\
(0.008)^{* * *}\end{array}$ & & & $\begin{array}{c}0.043 \\
(0.006)^{* * *}\end{array}$ \\
\hline Father's Edu: \% GRAD DEGREE & & & $\begin{array}{c}0.048 \\
(0.007)^{* * *}\end{array}$ & & & $\begin{array}{c}0.073 \\
(0.008)^{* * *}\end{array}$ & & & $\begin{array}{c}0.060 \\
(0.006)^{* * *}\end{array}$ \\
\hline Additional Fixed Effects: & $\begin{array}{c}\text { Year } \\
\text { School } \\
\text { Country }\end{array}$ & $\begin{array}{r}Y e \\
\text { School* }\end{array}$ & $\begin{array}{l}\text { ar } \\
\text { Country }\end{array}$ & $\begin{array}{c}\text { Year } \\
\text { School } \\
\text { Country }\end{array}$ & $\begin{array}{r}Y \\
\text { School* }\end{array}$ & Country & $\begin{array}{c}\text { Year } \\
\text { School } \\
\text { Country }\end{array}$ & $\begin{array}{r}Y \\
\text { School }\end{array}$ & $\begin{array}{l}\text { ear } \\
\text { Country }\end{array}$ \\
\hline Observations & 36218 & 36218 & 30797 & 36218 & 36218 & 30797 & 36218 & 36218 & 30797 \\
\hline R-squared & 0.57 & 0.67 & 0.72 & 0.4 & 0.53 & 0.57 & 0.54 & 0.65 & 0.69 \\
\hline
\end{tabular}

Note: Unit of observation is pseudo-school*country-of-origin*year. Regressions are weighted by population number of score reports. Standard errors are clustered by pseudo-school*country-of-origin cells. 
Table 5: Timing of Policy and SAT Score Response, Varied Approaches

\begin{tabular}{|lcccccc|}
\hline & $(1)$ & $(2)$ & $(3)$ & $(4)$ & $(5)$ & $(6)$ \\
Dependent Variable: & Math & Verbal & & \multicolumn{2}{c}{ Average SAT Score } & \\
Bound by H-1B Visa Cap & -9.908 & 0.105 & -9.804 & -15.932 & -9.583 & -13.652 \\
& $(2.313)^{* * *}$ & $(2.675)$ & $(3.638)^{* * *}$ & $(4.017)^{* * *}$ & $(3.509)^{* * *}$ & $(3.950)^{* * *}$ \\
Observations & 36218 & 36218 & 36218 & 36218 & 36218 & 36218 \\
R-Squared & 0.69 & 0.57 & 0.67 & 0.67 & 0.67 & 0.67 \\
& & & & & & \\
Dependent Variable: & In(Math) & In(Verbal) & & In(Average SAT Score) & \\
Bound by H-1B Visa Cap & -0.014 & 0.003 & -0.006 & -0.011 & -0.006 & -0.009 \\
& $(0.004)^{* * *}$ & $(0.005)$ & $(0.003)^{* *}$ & $(0.003)^{* * *}$ & $(0.003)^{* *}$ & $(0.003)^{* * *}$ \\
Observations & 36218 & 36218 & 36218 & 36218 & 36218 & 36218 \\
R-Squared & 0.68 & 0.57 & 0.67 & 0.67 & 0.67 & 0.67 \\
Robust standard errors in parentheses & & & & & \\
* significant at 10\%; ${ }^{* *}$ significant at 5\%; *** significant at 1\% & & & \\
Fixed Effects: SAT Date, School*Country & & & & & \\
\hline
\end{tabular}

Note: Unit of observation is pseudo-school*country-of-origin*year. Regressions are weighted by population number of score reports. Standard errors are clustered by pseudo-school*country-oforigin cells. Estimates assume different dates for individual responses to announced policy changes as described in the text. 
Table 6: Results When Excluding Potential Outlying Countries

\begin{tabular}{|c|c|c|c|}
\hline & (1) & (2) & (3) \\
\hline Excluded Countries: & $\begin{array}{c}\text { China, India, } \\
\text { Bulgaria, Romania }\end{array}$ & Canada & Singapore \\
\hline Dependent Variable: & \multicolumn{3}{|c|}{ Average SAT Score } \\
\hline \multirow[t]{2}{*}{ Bound by H-1B Visa Cap } & -9.553 & -14.958 & -7.735 \\
\hline & $(3.856)^{* *}$ & $(4.953)^{* * *}$ & $(4.229)^{*}$ \\
\hline Observations & 32331 & 33844 & 35341 \\
\hline R-Squared & 0.67 & 0.66 & 0.65 \\
\hline Dependent Variable: & \multicolumn{3}{|c|}{ In(Average SAT Score) } \\
\hline \multirow[t]{2}{*}{ Bound by H-1B Visa Cap } & -0.006 & -0.010 & -0.005 \\
\hline & $(0.003)^{*}$ & $(0.004)^{* *}$ & (0.004) \\
\hline Observations & 32331 & 33844 & 35341 \\
\hline R-Squared & 0.67 & 0.66 & 0.66 \\
\hline \multicolumn{4}{|c|}{ Robust standard errors in parentheses } \\
\hline \multicolumn{4}{|c|}{${ }^{*}$ significant at $10 \% ;{ }^{* *}$ significant at $5 \% ;{ }^{* * *}$ significant at $1 \%$} \\
\hline \multicolumn{2}{|c|}{ Fixed Effects: SAT Date, School*Country } & & \\
\hline
\end{tabular}

Note: Unit of observation is pseudo-school*country-of-origin*year. Regressions are weighted by population number of score reports. Standard errors are clustered by pseudo-school*country-oforigin cells. Estimates assume different dates for individual responses to announced policy changes as described in the text. 
Table 7: Results by College Type \& Tier

\begin{tabular}{|c|c|c|c|c|c|}
\hline \multicolumn{6}{|c|}{$\begin{array}{c}\text { Type \& Tier Specific Coefficients on Binding H-1B Policy } \\
\text { Dependent Variable: Average SAT Score }\end{array}$} \\
\hline \multicolumn{2}{|c|}{ School Type } & \multicolumn{2}{|c|}{ School Tier } & \multicolumn{2}{|l|}{ School Type \& Tier } \\
\hline Research & -7.537 & Top & -8.466 & General Effect & -14.061 \\
\hline & $(3.897)^{*}$ & & $(4.047)^{* *}$ & & $(3.957)^{* * *}$ \\
\hline Liberal Arts & -16.547 & Middle & -13.165 & Differential for Top Research Schools & 8.411 \\
\hline & $(5.389)^{* * *}$ & & $(4.958)^{* * *}$ & & $(4.205)^{* *}$ \\
\hline Masters & -14.371 & Bottom & -10.670 & & \\
\hline & $(7.006)^{* *}$ & & (6.539) & & \\
\hline Baccalaureate & -23.813 & & & & \\
\hline & $(13.787)^{*}$ & & & & \\
\hline Observations & 36218 & Observations & 36218 & Observations & 36218 \\
\hline R-Squared & 0.67 & R-Squared & 0.67 & R-Squared & 0.67 \\
\hline \multicolumn{6}{|c|}{ Robust standard errors in parentheses } \\
\hline \multicolumn{6}{|c|}{$*$ significant at $10 \% ; * *$ significant at $5 \% ; * * *$ significant at $1 \%$} \\
\hline \multicolumn{6}{|c|}{ Fixed Effects: SAT Date, School*Country } \\
\hline
\end{tabular}

Note: Unit of observation is pseudo-school*country-of-origin*year. Regressions are weighted by population number of score reports. Standard errors are clustered by pseudo-school*country-oforigin cells. Estimates assume different dates for individual responses to announced policy changes as described in the text. 
Table 8: Effect of Restrictive H-1B Policy on Demographic Composition of Prospective International Students

\begin{tabular}{|c|c|c|c|c|c|c|c|}
\hline & (1) & (2) & (3) & (4) & (5) & (6) & (7) \\
\hline Dependent Variable: & \% Female & $\%$ Asian & \% Black & \% Hispanic & $\%$ White & $\begin{array}{l}\text { \% Sure to Apply for } \\
\text { Aid }\end{array}$ & $\begin{array}{l}\text { \% Sure to Pursue } \\
\text { Advanced Degree }\end{array}$ \\
\hline Bound by H-1B Visa Cap & $\begin{array}{c}0.005 \\
(0.011)\end{array}$ & $\begin{array}{c}-0.076 \\
(0.014)^{* * *}\end{array}$ & $\begin{array}{l}-0.001 \\
(0.004)\end{array}$ & $\begin{array}{l}-0.003 \\
(0.003)\end{array}$ & $\begin{array}{c}0.059 \\
(0.014)^{* * *}\end{array}$ & $\begin{array}{c}0.044 \\
(0.012)^{* * *}\end{array}$ & $\begin{array}{c}0.084 \\
(0.017)^{* * *}\end{array}$ \\
\hline Observations & 36213 & 35226 & 35226 & 35226 & 35226 & 34079 & 33763 \\
\hline R2 & 0.31 & 0.79 & 0.79 & 0.82 & 0.76 & 0.44 & 0.30 \\
\hline \multicolumn{8}{|c|}{$\begin{array}{l}\text { Robust standard errors in parentheses } \\
{ }^{*} \text { significant at } 10 \% ;{ }^{* *} \text { significant at } 5 \% ; * * * \text { significant at } 1 \% \\
\text { Fixed Effects: SAT Date, School*Country }\end{array}$} \\
\hline
\end{tabular}

Note: Unit of observation is pseudo-school*country-of-origin*year. Regressions are weighted by population number of score reports. Standard errors are clustered by pseudo-school*country-oforigin cells. 
Table 9: Effects of Restrictive H-1B Policy by Quintile of the International Student Ability Distribution

\begin{tabular}{|c|c|c|c|c|c|}
\hline Quintile: & Bottom & 2nd & Middle & 4th & Top \\
\hline (SAT Score Range) & $(400-1000)$ & $(1010-1120)$ & $(1130-1220)$ & $(1230-1320)$ & $(1330-1600)$ \\
\hline Dependent Variable: & \multicolumn{5}{|c|}{ Share of SAT Score Reports } \\
\hline \multirow[t]{2}{*}{ Bound by H-1B Visa Cap } & -0.015 & 0.029 & 0.004 & 0.014 & -0.032 \\
\hline & $(0.007)^{* *}$ & $(0.008) * * *$ & $(0.009)$ & $(0.011)$ & $(0.010) * * *$ \\
\hline R-Squared & 0.51 & 0.30 & 0.24 & 0.25 & 0.53 \\
\hline Dependent Variable: & \multicolumn{5}{|c|}{ Number of SAT Score Reports } \\
\hline \multirow[t]{2}{*}{ Bound by H-1B Visa Cap } & -0.989 & 3.480 & 0.073 & 0.058 & -17.970 \\
\hline & $(0.574)^{*}$ & $(2.545)$ & $(1.828)$ & $(1.871)$ & $(9.265)^{*}$ \\
\hline R-Squared & 0.53 & 0.63 & 0.75 & 0.75 & 0.77 \\
\hline \multicolumn{6}{|c|}{ Robust standard errors in parentheses } \\
\hline \multicolumn{6}{|c|}{$*$ significant at $10 \% ; * *$ significant at $5 \% ; * * *$ significant at $1 \%$} \\
\hline \multicolumn{6}{|c|}{ Fixed Effects: SAT Date, School*Country } \\
\hline Observations: 36139 & & & & & \\
\hline
\end{tabular}

Note: Unit of observation is pseudo-school*country-of-origin*year. Dependent variable measures the share (or number) of score reports received by a school $s$ from citizens of country $c$ by each quintile of the international student ability distribution (as determined in the pre-binding policy period). More details are available in the text. Regressions are weighted by population number of score reports. Standard errors are clustered by pseudo-school*country-of-origin cells. 
Table 10: Case Study of Applicants to a Highly-Selective University

\begin{tabular}{|c|c|c|c|c|}
\hline Dependent Variable: & $\begin{array}{c}(1) \\
\text { Math SAT }\end{array}$ & $\begin{array}{c}(2) \\
\text { Verbal SAT }\end{array}$ & $\begin{array}{c}\text { (3) } \\
\text { Math + } \\
\text { Verbal }\end{array}$ & $\begin{array}{l}\text { (4) } \\
\text { High School } \\
\text { GPA }\end{array}$ \\
\hline & \multicolumn{4}{|c|}{ Dependent Variable Measured in Levels } \\
\hline Bound by H-1B Visa Cap & $\begin{array}{c}-13.284 \\
(4.992)^{* * *}\end{array}$ & $\begin{array}{l}-0.481 \\
(6.396)\end{array}$ & $\begin{array}{c}-13.765 \\
(10.454)\end{array}$ & $\begin{array}{c}-0.093 \\
(0.038)^{* *}\end{array}$ \\
\hline Observations & 612 & 612 & 612 & 612 \\
\hline \multirow[t]{2}{*}{ R-squared } & 0.85 & 0.65 & 0.75 & 0.68 \\
\hline & \multicolumn{4}{|c|}{ Dependent Variable Measured in Logs } \\
\hline Bound by H-1B Visa Cap & $\begin{array}{c}-0.022 \\
(0.008)^{* * *}\end{array}$ & $\begin{array}{c}0 \\
(0.011)\end{array}$ & $\begin{array}{c}-0.012 \\
(0.008)\end{array}$ & $\begin{array}{c}-0.028 \\
(0.012)^{* *}\end{array}$ \\
\hline Observations & 612 & 612 & 612 & 612 \\
\hline R-squared & 0.84 & 0.64 & 0.73 & 0.65 \\
\hline \multicolumn{5}{|c|}{$\begin{array}{l}\text { Robust standard errors in parentheses } \\
* \text { significant at } 10 \% ; * * \text { significant at } 5 \% ; * * \text { significant at } 1 \% \\
\text { Fixed Effects: Country and Academic Year } \\
\text { Constant and Other Coefficients Suppressed }\end{array}$} \\
\hline
\end{tabular}

Note: Unit of observation is country-of-origin*year. Regressions are weighted by number of applicants. Standard errors are clustered by country of origin. 


\section{Figure 1: H-1B Issuances and Undergraduate Enrollment}

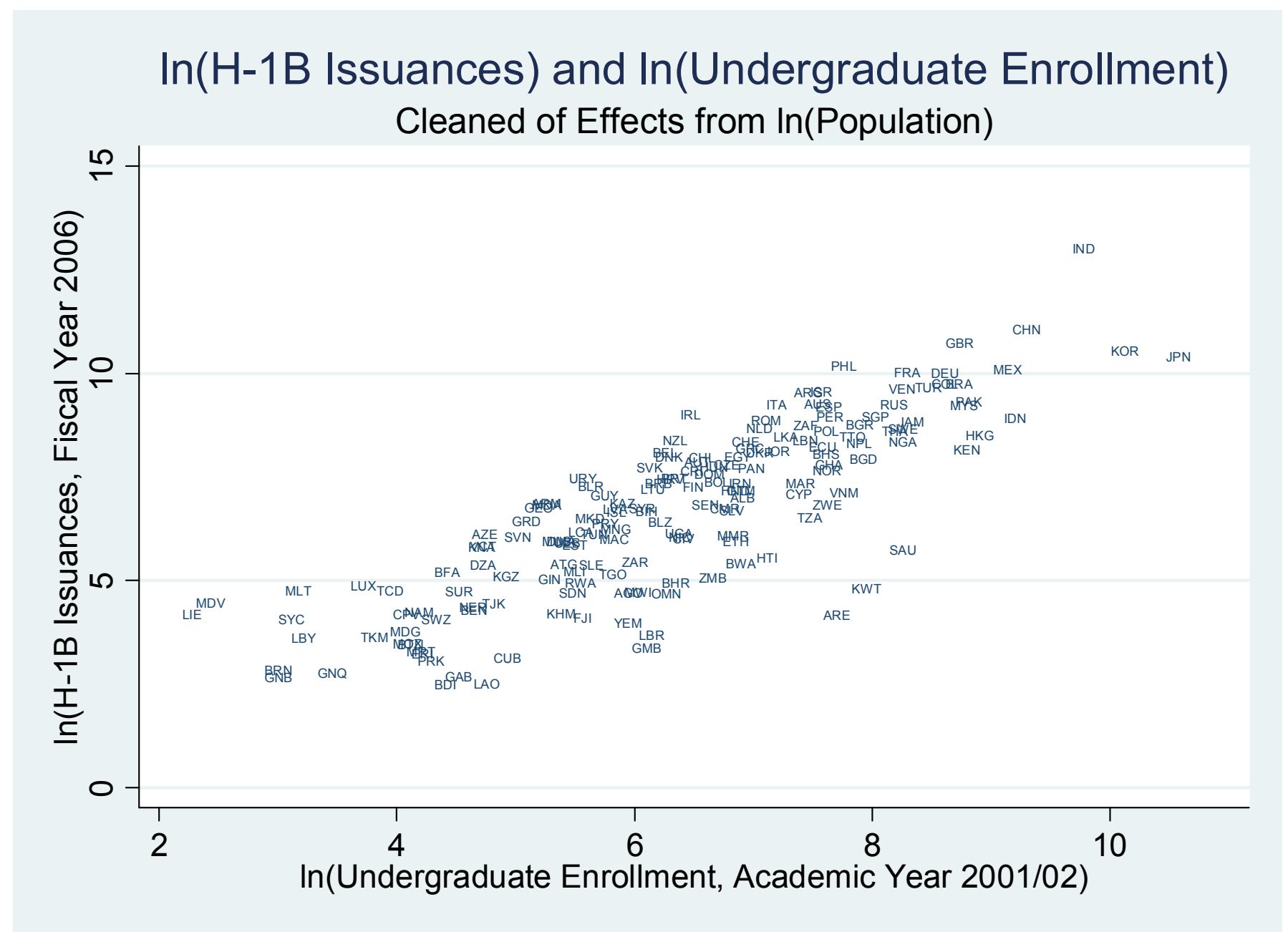

Note: Graph displays predicted values and residuals of H-1B Issuances (in Fiscal Year 2006) for a cross-country regression on Undergraduate Enrollment (Academic Year 2001/02) and Population (2002), all measured in logs. Regression omits Canada since its citizens only need to meet H-1B (or TN) criteria but do not require an actual visa. 


\section{Figure 2: Theoretical Model of Migration Decision}

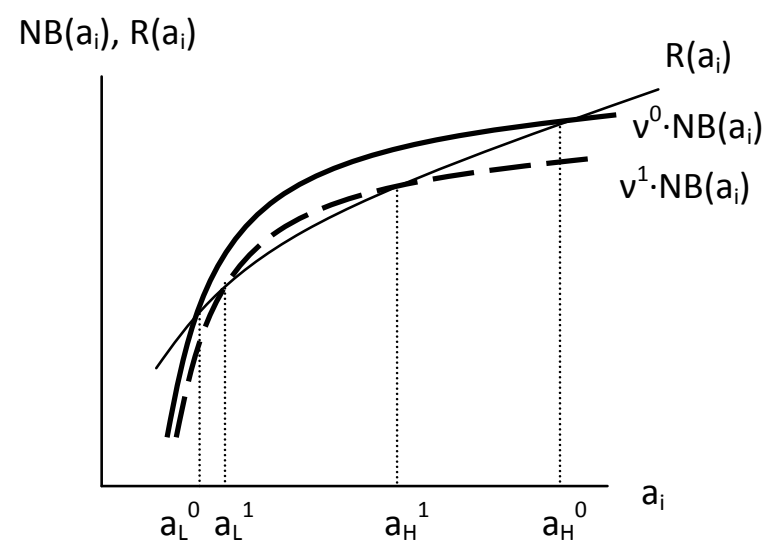

Figure 1a: The Net Benefit is More Concave than the Reservation Wage. Immigration policy becomes more restrictive, reducing the probability of finding employment from $v^{0}$ to $v^{1}$. This reduces ability groups who would immigrate from $\mathrm{a}_{\mathrm{H}}{ }^{0}<\mathrm{a}_{\mathrm{i}}<\mathrm{a}_{\mathrm{L}}{ }^{0}$ to $\mathrm{a}_{\mathrm{H}}{ }^{1}<\mathrm{a}_{\mathrm{i}}<\mathrm{a}_{\mathrm{L}}{ }^{1}$.

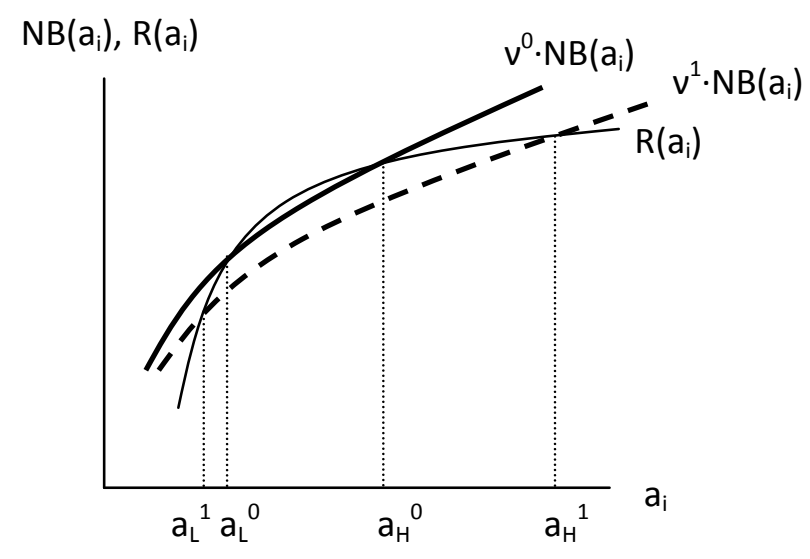

Figure $1 \mathrm{~b}$ : The Net Benefit is Less Concave than the Reservation Wage. Immigration policy becomes more restrictive, reducing the probability of finding employment from $v^{0}$ to $v^{1}$. This reduces ability groups who would immigrate from $a_{i}<a_{L}{ }^{0}$ and $a_{i}>a_{H}{ }^{0}$ to $a_{i}<a_{L}{ }^{1}$ and $a_{i}>a_{H}{ }^{1}$. 


\section{Figure 3: Visa Issuances}
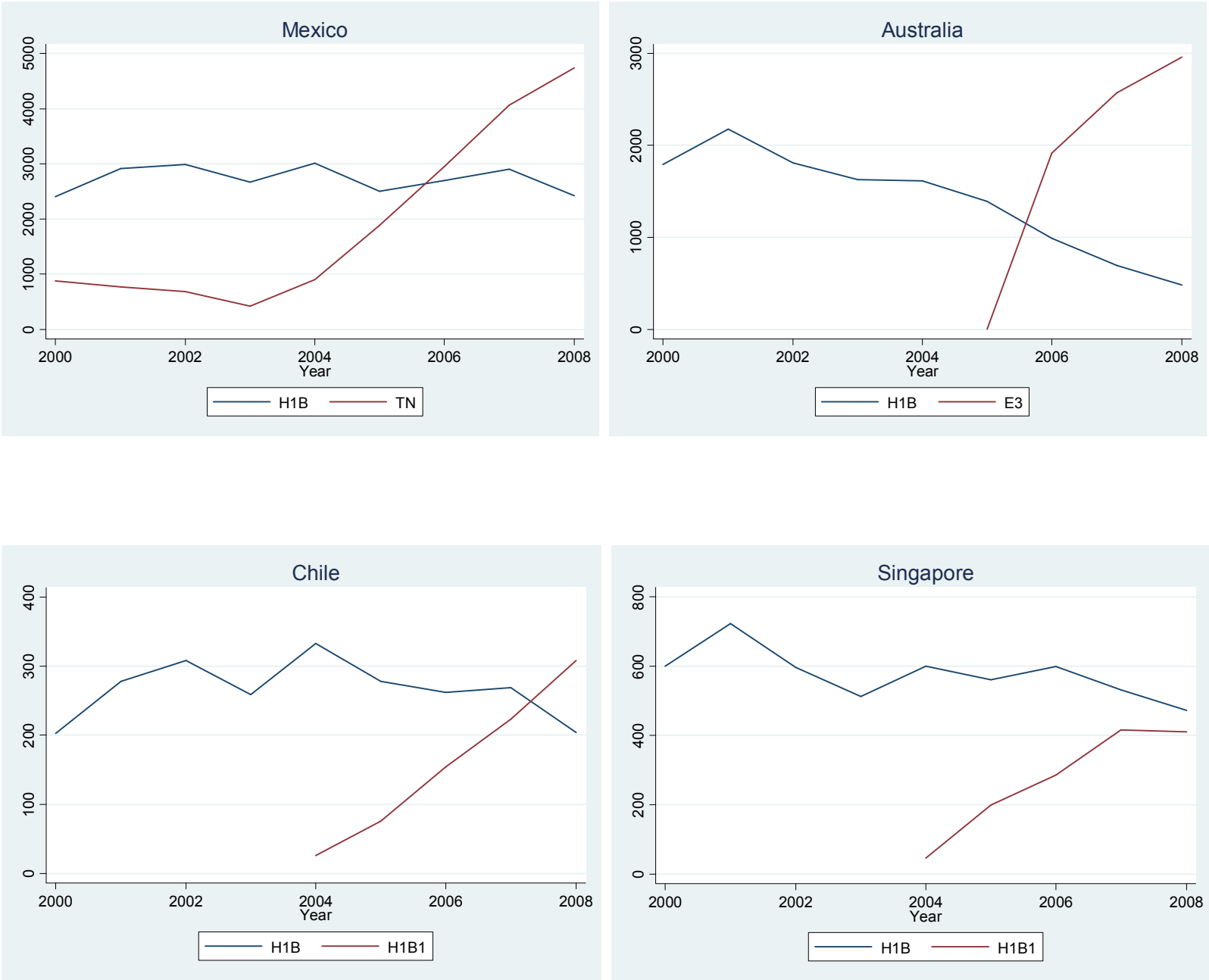

Note: Charts describe the number of new visa issuances by type and country since 2000 (Source US State Department). College-educated citizens from Canada, Mexico, Australia, Chile, and Singapore have viable alternatives to the $\mathrm{H} 1 \mathrm{~B}$ visa. Canadian citizens do not require $\mathrm{H}-1 \mathrm{~B}$ or TN visas to work in the United States, but do need to meet H-1B or TN criteria. 


\section{Figure 4: Average SAT Scores of Enrollees and College Rank}

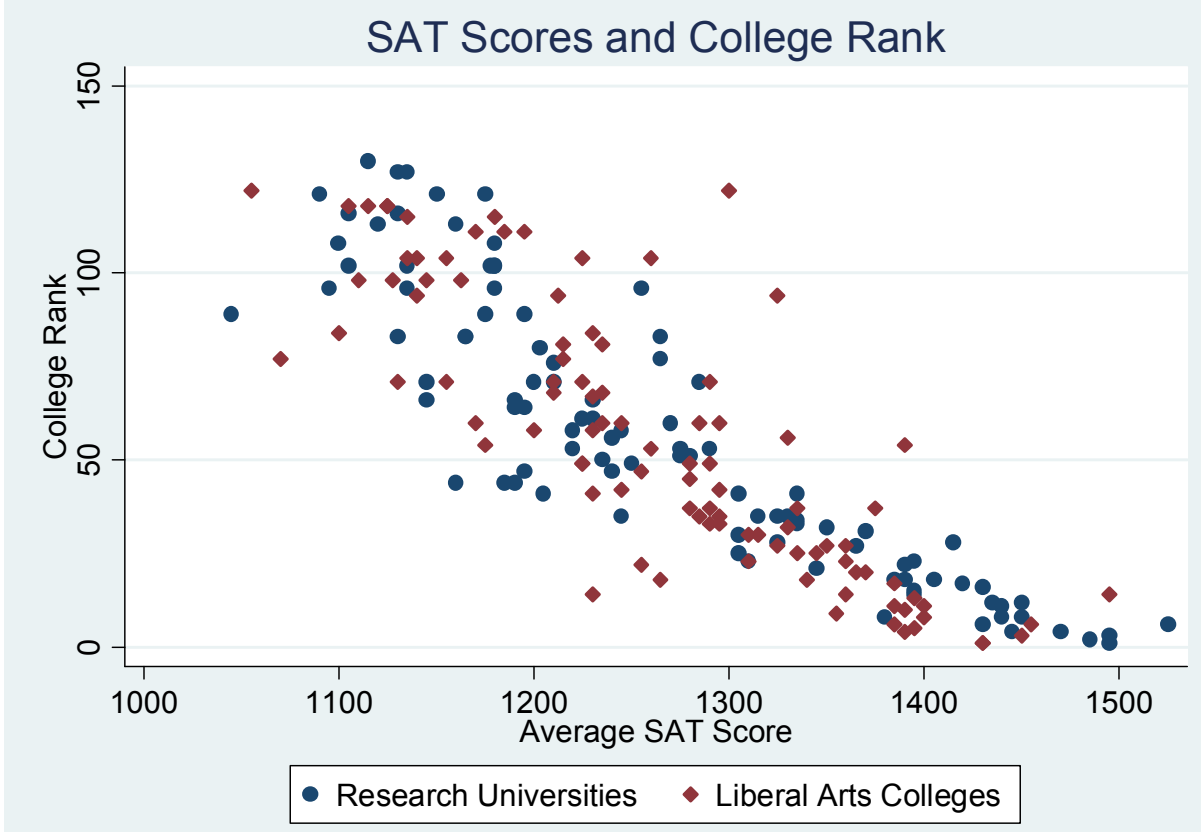

Note: Scatterplot records the average of the 1st and 3rd quartile SAT scores of enrolled students and the 2009 US News and World Reports America's Best Colleges rank of 195 national research universities and liberal arts colleges. A bivariate regression would produce a coefficient on Average SAT Score of -0.293 and an $\mathrm{R}^{2}$ of 0.74 . 